\title{
Mezhep Çatışmasına Bir Etnik Grup ve Yerel Bağlam Üzerinden Bakmak: Irak Türkmenleri ve Telafer Örneği
}

\author{
Tunahan Y1ldı*
}

Öz

Bu çalışma, özellikle 2003 işgalinden beri Irak'la alakalı en çok tartışılan konulardan birisi olan mezhep çatışmasına ve Irak toplumuna yönelik en başat sınıflandırmalardan olan mezhepsel gruplara yönelik Irak Türkmenlerinin ortaya çıarabileceği potansiyelden hareket etmiştir. 2003 sonrası mezhep çatışmasının parametrelerinin ve etkilerinin neler olduğu sorusundan hareketle, Irak Türkmenleri arasında yoğun kitlesel gerilimlerin yaşandığı bir kent olarak öne çıkan Telafer vakasını inceleyen bu çalışmada ilk olarak, mezhepçiliğe nasıl bir kuramsal çerçeve çizilebileceği ilkçi, araçsalcı ve inşacı olmak üzere üç temel yaklaşımın ış1ğında sorgulanacaktır. Buna göre mevcut kuramsal yaklaşımların mezhepçiliğin analizinde çok az işlendiği ancak inşacı bir yaklaşımın özellikle Telafer'i anlamada yardımcı olacağı iddia edilecektir. İkinci olarak, Telafer'de neden ve nasıl bir çatışma yaşandığı tartışılacaktır. Bu bölümde, Telafer'deki mezhepçiliğin ana yürütücüleri olarak güvenlik güçlerinin, direnişçi grupların ve aşiretlerin öne çıktı̆̆ 1 , ABD'nin yerel uygulamalarının bunların işlemlerini kolaylaştırdığı ve ülkedeki siyasi atmosferin ürettiği mezhepçi imgelerin, oluşan güvensizlik ortamının ve bölgedeki aşiret düzeninin mezhepçiliği sürdürülebilir kıldığı savunulacaktır. Üçüncü olarak, DAEŞ işgalleri sebebiyle Telafer'den Türkiye'ye sığınmış Irak Türkmenleri arasında Ankara'da yazar tarafindan yapılan saha araştırmasında kullanılan ve mezhepçiliğin hangi boyutlarda olduğunu anlamaya yönelik anketin sonuçları sunulacaktır. Bulgular, mezhepçiliğin geniş bir toplumsal tabandan mahrum olduğuna ancak önemli bir inşa gücüne ve zorlayıcılığa sahip olduğuna işaret edecektir.

Anahtar Kelimeler: Irak, Mezhepçilik, Telafer, Türkmenler, İnşacıllk

Arş.Gör., Orta Doğu Teknik Üniversitesi, Uluslararası İlişkiler, tunahan@metu.edu.tr 


\title{
Looking at Sectarian Conflict through an Ethnic Group and a Local Context: The Case of Iraqi Turkmens and Tal Afar
}

\author{
Tunahan Yildı*
}

\begin{abstract}
This study relies on the latent core of the Iraqi Turkmens regarding sectarian conflicts and groups that have been major topics and classifications of Iraq especially since 2003. In search of parameters and impacts of the post-2003 sectarian conflict, this study examines the case of Tal Afar, a town of mass strifes of Iraqi Turkmens. In the first instance, how to approach theoretically to sectarianism will be investigated in the light of primordialism, instrumentalism and constructivism. Accordingly, the present approaches have been underdeveloped in the analysis of sectarianism, but constructivism can be recruited to understand Tal Afar. In the second instance, why and how the conflict occurred in Tal Afar will be discussed. It will be argued that the security forces, insurgent groups and tribes emerged as the main drivers of sectarianism; the local practices of the US army catalyzed their activities; and sectarian images, insecurity environment and tribal order rendered sectarianism sustainable. In the third instance, the results of the survey that was conducted by the author among ISIS-victim Iraqi Turkmen refugees in Ankara to measure the magnitude of sectarianism will be presented. The findings will indicate that sectarianism lacks large social base but has significant constructive power and coercivity.
\end{abstract}

Keywords: Iraq, Sectarianism, Tal Afar, Turkmens, Constructivism

Res.Asst, Middle East Technical University, International Relations, tunahan@metu.edu.tr 


\section{Giriş}

Bu makale, Türk kamuoyunun Irak Türkmenlerine olan aşinalığının öne çıkartmadığ 1 üç temel hususa dayanmaktadır. Birincisi, Irak Türkmenlerinin Irak'ın kuzey-batısından orta-doğusuna uzanan bir çapraz şerit içerisinde, Irak'taki birçok mezhepsel ve etnik grubun kesişim ya da sınır bölgelerinde bulunması; Sincar'da Yezidilerden Musul'da Sünni Araplara, Erbil'de Kürtlerden Diyala'da Şii Araplara kadar pek çok farklı etnik ve mezhepsel grupla etkileşim halinde ve yan yana ya da birlikle yaşamasıdır. Dolayısıyla, Irak Türkmenleri üzerine yapılacak çalışmalar, sadece Irak Türkmenlerine yönelik çıkarımlar ihtiva etmez, aynı zamanda Irak toplumuyla alakalı olguların ortaya çıkarılmasına katkı sağlar. İkincisi, Irak Türkmenlerinin Irak'in sosyo-politik tarihinden ve gündeminden neredeyse hiçbir dönemde izole olamaması, tam tersine bu tarihin ve gündemin yansımalarını kendi bölgelerinde önemli oranda hissetmeleridir. Bugün de ihtilaflı bölgeler, Kerkük'ün statüsü, DAEŞ işgalleri ve DAEŞ'e karş1 operasyonlar, Haşdi Şaabi gibi Irak'in pek çok kritik meselesinin tam ortasında yer almaktadırlar. Diğer bir deyişle, Irak Türkmenlerinin incelenmesi Irak tarihine ve siyasetine yönelik daha geniş çıkarımlar elde etmenin önünü açacaktır. Üçüncüsü, Türkiye'deki yaygın yaklaşımın aksine Irak Türkmenleri olarak adlandırılan topluluğun yekpare bir etnik grup teşkil etmemesi; aşiret, dini, milli, etnik ${ }^{1}$ ve mezhepsel kimlikleri içeren en az beş iç içe kimlik boyutundan meydana gelmesidir. Bu çoklu kimlikler, Orta Doğu ve Irak'ta kimlikle alakalı meselelere yönelik bir bakış geliştirmede yardımcı olma imkânına sahiptir.

$\mathrm{Bu}$ çalışma, bahsedilen bu üç hususla alakalı olarak, mezhep çatışmasına ve mezhepsel gruplara yönelik Irak Türkmenlerinin ortaya çıkarabileceği potansiyelden hareket etmiştir. Sünni ve Şii olarak iki mezhepsel grubun oluşturduğu Irak Türkmenleri, bulundukları alanlar itibariyle 2003 sonrasında Irak'ın temel dinamiklerinden olan mezhepçiliğin ve mezhep kim-

\footnotetext{
Çalışmada milli ve etnik kimlikler arasında yapılan bu ayrım, etnisite ve milliyetçilik literatüründe milli kimliğin siyasal referanslarla ve özellikle devlet ya da benzeri yapılarla tanımlanmasına, etnik kimliğin ise daha çok kültürel ve toplumsal ögelerle tarif edi lmesine yönelik bir kavramsallaştırmaya dayanmaktadır. Bu ayrıma dair tartı̧̧malardan örnekler için bakınız: Steve Fenton, Ethnicity, Cambridge: Polity Press, 2010, s. 52; Thomas Hylland Eriksen, Ethnicity and Nationalism, London \& Virginia: Pluto Press, 2002, s. 7. Bu kapsamda çalışmada, milli kimlik ile Iraklılık kimliği, etnik kimlik ile Türkmen kimliği kastedilmektedir.
} 
liğinin kuvvetli olduğu bölgelerle yan yana ya da iç içedir. Bu noktada, Musul'a bağlı Telafer kenti, 2003 öncesi herhangi bir mezhepsel mobilizasyon emaresi göstermemesine rağmen 2003 sonrası Irak'ının mezhep çatışması atmosferinin dışında kalamamış ve Türkmenler arasında mezhep çatışmasının uzun yıllar geniş anlamda tecrübe edildiği yegâne bölge olmasıyla öne çıkmıştır. Bu makale, Irak’taki 2003 sonrası mezhep çatışmasının parametrelerinin ve etkilerinin neler olduğunu sorgulamaktadır. Kapsamını bir yerel bağlam olarak Telafer vakasıyla sınırlı tutacaktır. Irak’taki mezhepçiliğe dair İngilizce ve Türkçe literatürün özellikle yerel bağlam analizlerinde, mezhepçiliğin parametre ve etkilerine yönelik bütüncül bakış açılarında ve Irak Türkmenlerinin başlı başına ve/veya mezhepçilik bağlamında akademik olarak incelenmesinde ciddi bir boşluk keşfeden bu makalenin amac1, bilhassa Türkçe literatürün bu noktalardaki zafiyetini gidermektir.

Vakanın konu açısından önemi beş ana maddeyle özetlenebilir: Bir yerel bağlamdaki mezhepçiliğin ülke ve bölgedeki önemi ilk olarak üretilen mezhepçi imgelerle alakalıdır. İmgeler, öteki-imgesi ve öz-imge olarak grupların kendileri ve birbirleri hakkındaki bilgi ve görüşlerine yeniden üretici biçimde sirayet eder; dolayısıyla vakanın incelenmesi, yerel bağlam ile geniş bağlam arasındaki karşılıklı ilişkinin anlaşılmasına yardımcı olur. İkinci olarak, yerel bağlam mezhepçiliğin hangi analiz biriminde çözümleneceğine dair ipuçları verir. Yerel bağlam analizlerinin birçok tabakanın etkileşimini yakından gösteren mikroskobik çalışmalar olduğu söylenebilir. Üçüncü olarak, 2003 sonrası geçirdiği evrimle Telafer, mezhepçiliğin inşasını açıkça gösteren bir vaka olarak öne çıkmaktadır. Irak'ın işgalinden önce sadece bir Türkmen kenti olarak bilinen Telafer, işgal sonrasında pek çok kez mezhepçi şiddetle anılmıştır ve bugün de DAEŞ ve Haşdi Şaabi bağlamında mezhepçi şiddetin geri döneceğine dair haberlerle gündeme gelmektedir. Dördüncü olarak, Telafer'deki çatışmadan hareketle Irak Türkmenleri arasında genel ve kapsamlı bir mezhep çatışmasından bahsetmek yanlış olsa da Türkmenler arasında tecrübe edilmiş bir mezhep çatışması vakası olmasıyla Telafer, Türkmenlere yönelik etnik boyutu genel geçer anlamda önceleyen bakışları sorgulatmaktadır. Özellikle Türkmen yazarların Irak Türkmenleri anlatılarında yekpare bir etnik grup sunulmaktadır ki tam tersine Telafer'deki mezhep çatışması Irak Türkmenlerinin çoklu kimliklerine dair önemli bir kesit sunmaktadır. Beşinci olarak, Irak'ta mezhep çatışmasının tecrübe edildiği bölgeler, büyük oranda Sünni ve Şii Araplar merkeze alınarak tartışılmakta ve bu tartışmalarda Türk- 
menler gibi gruplar etnikliklerinin öncelenmesiyle kapsam dışında tutulmaktadır. Telafer kenti, bir yandan Irak'taki mezhepçiliğin Arap-merkezli okumalarını Irak'ta etnik olarak azınlıkta bulunan Türkmenler aracılığıyla sorgulatmakta, diğer yandan mezhepçiliğin yayılım gücünün etnik bir azınlığa dahi nasıl ulaştığını göstermektedir.

Çalışma, nitel ve nicel metotlara birlikte dayanarak karma bir bilimsel yöntem takip etmektedir. Çalışmada öncelikle, bölgesel ve yerel mezhepçiliğe nasıl bir kuramsal çerçeve çizilebileceği ilkçi, araçsalcı ve inşacı olmak üzere üç temel kuramsal yaklaşımın ışığında sorgulanacaktır. Takip eden bölümde, Telafer' de nasıl ve neden bir çatışma yaşandığı sorusundan hareketle Telafer'deki mezhep çatışmasının bağlamı, süreçleri ve aktörleri çizilen teorik çerçeve içerisinde büyük oranda ikincil kaynaklara ve daha az oranda birincil kaynaklara dayanılarak aktarılacaktır. Daha sonra, DAEŞ işgalleri sebebiyle Telafer'den Türkiye'ye sığınmış Irak Türkmenleri arasinda 2 Şubat 2016-15 Nisan 2016 tarihleri arasında Ankara'da yazar tarafından yapılan saha araştırmasında kullanılan ve mezhepçiliğin hangi boyutlarda olduğunu ve parametrelerinin neler olduğunu anlamaya yönelik anketin nicel sonuçları ve çıkarımları sunulacaktır.

\section{Kavramsal ve Kuramsal Çerçeve}

Mezhepçilik üzerine literatürün olaylar üzerine aşırı odaklanması, konuya yönelik kuramsal yaklaşımların zenginleşememesine yol açmıştır. $\mathrm{Bu}$ az gelişmişliğe bağlı olarak bu yaklaşımların tartışılması çeşitli sorunlarla karşılaşacaktır ki bunlardan en önemlisi aynı yaklaşımın farklı disiplinlerdeki farklı yansımalarının mezhepçilik gibi disiplinler arası karakteri son derece açık bir konuda bir araya getirilmesidir. Bu bölümde öncelikle, büyük oranda etnisite ve milliyetçilik çalışmalarından devşirilerek mezhepçiliğin analizinde öne çıan ve konuyla ilgili olarak ulusal literatürde hemen hemen hiç temas edilmeyen üç çatı yaklaşımın temel argümanlarına ve sorunlarına değinilecektir. Böyle bir çerçeve çizilirken burada tartışılacak olan yaklaşımların haricinde bunlarla çok fazla ortak noktası bulunan Helle Malmvig' in ${ }^{2}$ güvenlikleştirme yaklaşımı ve Toby Dodge'un ${ }^{3}$ tarihsel

Helle Malmvig, "Coming in from the Cold: How We May Take Sectarian Identity Politics Seriously in the Middle East without Playing to the Tunes of Regional Power Elites", POMEPS Briefings, 2016, sy. 28, s. 8-12.

Toby Dodge, "Seeking to Explain the Rise of Sectarianism in the Middle East: The Case Study of Iraq", POMEPS Briefings, 2016, sy. 28, s. 22-28. 
sosyolojisi gibi daha spesifik perspektiflerin de mevcut olduğu not edilmelidir.

Bu çatı yaklaşımlardan birincisi, mezhepçiliği verili, doğal, değişmez, uzlaşmaya kapalı ve çok eskiden gelen bir olgu olarak alan ilkçi (primordialist) yaklaşımdır. Bu yaklaşımda, farklılığın şiddet üzerinde doğrudan etkili olduğu varsayılarak mezhepçilikle mezhepsel kimliklerin eşitlendiğ söylenebilir. Bu yaklaşıma göre Irak bağlamında mezhepçilik, Irak'ın işgaliyle kendisini baskıdan kurtararak yeniden ifade etmesi olarak görünür. Başka bir deyişle, ilkçilere göre, Irak toplumu birbirini katletmek için uzun y1llardır bekleyen dinlerin ve etnisitelerin karmaşık bir kompozisyonundan fazlası değildir. ${ }^{4}$ Genel olarak medyada ve bizzat mezhepçi söylemlerde sıkça kendini gösteren ilkçilik, literatürde özellikle mezhepçiliğe tarihsel yaklaşımlarda kendini ifade etmektedir. Bunlara örnek olarak, Hadi Alevi ve Ala'a Lavi'nin ${ }^{5}$ mezhepçiliği Sünnilik ve On İki İmam Şiiliğinin 7. yüzyılda kristalize olmasında bularak mezhepçilik ile mezhep kimliği arasında ayrım gözetmeyen çalışması, Raşid el-Hayyun'un ${ }^{6}$ mezhepçiliği 'Osmanlıların Şiilere dört yüz yıllık baskısının ifadesi' olarak bulan kitabı ve Vali Nasr' $1 n^{7}$ Irak'taki Sünni-Şii ilişkilerini ‘birbiriyle yarışan teolojilerin ve kutsal tarih anlayışlarının savaşı' olarak gören yaklaşımı verilebilir. Birçok sembolün yüzyıllar öncesinden getirilmesinden ve yüzyıllar boyunca benzer formatlarda işlenmesinden dolayı ilkçilik yadsınamaz argümanlara sahiptir ancak Sünni ve Şii toplulukların çatışma yaşamadığı dönemler de bir parantez olarak görülemez. Mesela, ilkçi yaklaşımı ilk bakışta yanlışlayacak biçimde yüzyıllar boyunca Sünni ve Şii Türkmenler Telafer'de mezhepsel çatışmanın olmadığı, hatta (ileride tartışılacağı üzere) mezhepsel kimliklerin kendini çok az geliştirebildiği bir ortamda bir arada yaşamışlardır. $^{8}$

Sami Ramadani, “The Sectarian Myth of Iraq”, The Guardian, 16 Haziran 2014.

Khalil F. Osman, Sectarianism in Iraq: The Making of State and Nation since 1920, London \& NY: Routledge, 2015, s. 12.

Ibid., s.12.

Vali Nasr, The Shia Revival: How Conflicts within Islam Will Shape the Future, NY: Norton, 2006, s. 20.

8 İlkçi yaklaşım üzerine etnisite çalışmalarındaki bazı tartışmalar için bakınız: Steve Fenton, Ethnicity, Cambridge: Polity Press, 2010, s. 73-90; Jack Eller and Reed Coughlan, "The Poverty of Primordialism", in Ethnicity, ed. John Hutchinson and Anthony D. Smith, Oxford: Oxford University Press, 1996, s. 45-51; Michael Freeman, "Theories of Ethnicity, Tribalism and Nationalism", in Ethnic Conflict, Tribal Politics: 
İkincisi, mezhepçilik olarak ele alınan olgunun ardındaki maliyet-kazanç hesaplamalarına, stratejik değerlendirmelere, güç/çıkar arayışlarına ve elit manipülasyonuna odaklanan araçsalcı (instrumentalist) yaklaşımdır. $\mathrm{Bu}$ yaklaşım, mezhepçiliğin verili ve doğal olduğu ve doğrudan miras alındığı tezini reddeder; siyasi, ekonomik ve sosyal amaçlar için bilinçli ve istekli biçimde üretildiğini savunur. Mezhepçilik üzerine literatürde en sık işlenen yaklaşımlardan birisi olan araçsalcılık, F. Gregory Gause'un ${ }^{9}$ mezhepçiliği Suudi Arabistan ile İran arasındaki soğuk savaş bağlamında ele alan ve yerele etki etmede kullanılan bir araç olarak gören yaklaşımında, Hasan Qarawee'nin ${ }^{10}$ mezhepçileşmeyi elitlerin siyasal mezhepçi söylemleri ve mobilizasyonu çerçevesinde tartışan makalesinde ve Marc Lynch' in ${ }^{11}$ mezhepçiliğin yoğunluğunu özsel değil, Irak'ın işgali, Suriye İç Savaşı ve İran'la yapılan nükleer müzakereler bağlamında siyasal bulan çalışmasında incelenebilir. Mezhepler ve mezhep grupları, güç mücadeleleri içinde 'kullanışlı müşteriler' olarak gerçekten bulunsa da araçsalcı yaklaşım, özellikle toplumsal düzeyde yukarıdan gelen mezhepçi argümanların aşağıda neden ve nasıl kabul gördügünü, yani manipülasyonun neden ve nası1 çalıştı̆̆ını açıklamaz ve mobilizasyonun neden belli bir formda gerçekleştiğine, söz konusu araçsallaştırmanın neden mezhepler üzerinden gerçekleştiğine, örneğin, etnisite ya da sınıflar üzerinden gerçekleşmediğine dair bilgi vermez. ${ }^{12}$

A Global Perspective, ed. Kenneth Christie, Richmond: Curzon Press, 1998, s. 1533; Edward Schatz, Modern Clan Politics: The Power of "Blood" in Kazakhstan and Beyond, Seattle: University of Washington Press, 2004, s. 3-20.

$9 \quad$ F. Gregory Gause, "Beyond Sectarianism: The New Middle East Cold War", Brookings Doha Center Analysis Paper, 2014, sy. 11.

10 Harith Hasan al-Qarawee, "Heightened Sectarianism in the Middle East: Causes, Dynamic and Consequences", ISPI Analysis, 2013, sy. 205, s. 1-2.

11 Marc Lynch, "Why Saudi Arabia Escalated the Middle East's Sectarian Conflict", The Washington Post, 4 Ocak 2016.

12 Araçsalcılığın etnisite merkezli tartışmalarından bazıları için bakınız: Michael Hetcher, "Ethnicity and Rational Choice Theory", in Ethnicity, ed. John Hutchinson and Anthony D. Smith, Oxford: Oxford University Press, 1996, s. 90-98; Michael Banton, "The Actor's Model of Ethnic Relations", in Ethnicity, ed. John Hutchinson and Anthony D. Smith, Oxford: Oxford University Press, 1996, s. 98-104; James McKay, "An Explanatory Synthesis of Primordial and Mobilisationist Approaches to Ethnic Phenomena", Ethnic and Racial Studies, 1982, c. 5, sy. 4, s. 395-418; George Scott, "A Resynthesis of Primordial and Circumstantial Approaches to Ethnic Group Solidarity: Towards and Explanatory Model", Ethnic and Racial Studies, c. 13, sy. 2, s. 147-171. 
Üçüncüsü, bu iki yaklaşımın arasında yer alan ve mezhep kimliği ile yapılar ve şartlar arasındaki etkileşimi, mezhepçi normların davranış üzerindeki etkisini, sosyal olarak inşa edilmişliği, dinamikliği ve çok boyutluluğu vurgulayan inşacı (constructivist) yaklaşımdır. İnşacılık, ilkçilerin tarihsel devamlılıklar üzerine olan kat1 vurgusundan ve araçsalcıların materyal olanlara düşünsel olanlar üzerinde verdikleri öncelikten kaçınır ve 'stratejiklik' ile 'verililik' arasında bir noktada belirir. Başka bir deyişle, bu yaklaşım elitlerin manipüle edebileceği bir temelin varlığını kabul eder ancak kimliğin ve çatışmanın bu temel üzerine sosyal olarak inşa edildiğini iddia eder ve materyal ve düşünsel yapılar arasındaki etkileşime vurgu yaparak bu inşa süreçlerine dikkat çeker. Bu yaklaşımın örnekleri, Fanar Haddad'ın ${ }^{13}$ mezhepsel sınırlar ve belli şartlar arasındaki etkileşime Körfez Savaşı ve Irak'ın işgali sonrası bağlamlarda odaklandığı ve mezhep kimliklerinin nasıl sürekli müzakere edildiğini gösterdiği kitabında ve Halil Osman' $1 n^{14}$ Irak'ta ulus-devlet inşası sürecindeki sorunlardan yola çıkarak mezhepçi ilkselliklerin inşasına odaklandığı çalışmasında görülebilir. Mezhepçiliği ne 'doğal olarak çatışmacı' ne de 'zorunlu olarak amaçlı' bir olgu olarak alan inşacı yaklaşım, birbirine bağlı çok fazla değişkeni işleme sokar ve bu değişkenlerin oluşturduğu süreçleri temel belirleyici olarak öne sürer ki bu durumda süreçleri ayrı değişkenlermiş gibi çalıştırmış olur; dolayısıyla inşacı bir açıklamanın sebep, süreç ve sonuç arasındaki ayrımların bulanıklığını netleştirmeye çalışması gerekir. ${ }^{15}$ Yine de sosyal süreçlere dikkat çekmesiyle ve odaklandığı değişkenlerin çok boyutluluğuyla inşacılığın bu yaklaşımlar içerisinde en geniş kuramsal donanıma sahip olduğu söylenebilir. ${ }^{16}$

13 Fanar Haddad, Sectarianism in Iraq: Antagonistic Visions of Unity, London: Hurst \& Company, 2011.

14 Osman, s.267.

15 Maja Zehfuss, Constructivism in International Relations: The Politics of Reality, Cambridge: Cambridge University Press, 2004, s. 88-93.

16 İnşacılığın etnisite çalışmalarındaki bazı yansımaları için bakınız: Joanne Nagel, "Constructing Ethnicity: Creating and Recreating Ethnic Identity and Culture", in New Tribalisms: The Resurgence of Race and Ethnicity, ed. Michael W. Hueghey, London: MacMillan Press, 1988, s. 237-272; Gerd Baumann, The Multicultural Riddle: Rethinking Ethnic and Religious Identities, NY: Routledge, 1999, s. 57-68; Cora Govers and Hans Vermeulen, "From Political Mobilization to the Politics of Consciousness", in The Politics of Ethnic Consciousness, ed. Cora Govers and Hans Vermeulen, NY: St. Martin's Press, 1997, 1-30; Stephan Cornell and Douglas Hartman, Ethnicity and Race: Making Identities in a Changing World, CA: Pine Forge Press, 1998, 72-101. 
Telafer'deki mezhep çatışması, ilkçilerin iddia ettiği gibi otoriter bask1 yapısının ortadan kalkmasıyla birlikte toplumsal düzeyde kendini yeniden üretmiş bir olgu değildir; aksine, temelde aktif ve dinamik bir şekilde mezhep kimlikleriyle beraber inşa edilmiş bir mezhepçilik söz konusudur. Ayrıca, anket sonuçlarının da ortaya çıkaracağı üzere Irak'ın genelinde olduğu gibi ${ }^{17}$ Telafer'de mezhepçiliğin ilkçi popülerlikten, ${ }^{18}$ yani ilkçi argümanların ihtiyaç duyduğu verili ve geniş toplumsal tabandan hem geçmişte hem de bugün yoksun olduğu söylenebilir. Öte yandan, tabakalar ve sosyal aktörler arası etkileşim, Telafer' deki mezhepçilik inşasının kilit noktasıdır ve araçsalcı yaklaşımların bu noktayı genellikle atladığı ve bu şekilde mezhepçiliği büyük oranda söylem düzeyinde bıraktığı görülmektedir. Ek olarak araçsalcılık, popülerliği ve toplumsal düzeyi yadsıyarak Telafer'deki çatışmayı 'süreçsiz' olarak ele alacaktır ve açıklayıcılıktan uzaklaşacaktır. $\mathrm{Bu}$ noktada, sosyal süreçleri vurgulayan ve yukarıdan yapılan dayatmaların etkisini de hesaba katan inşacı yaklaşım, özellikle mezhepçileşme ve mezhep kimliği konsolidasyonu süreçlerini anlamada öne çıkmaktadır. İnşacı bir çerçeve içerisinde Telafer'deki mezhep çatışmasını anlamaya odaklanan bu makalede sebep, süreç ve sonuç arasındaki bulanıklıklar giderilerek inşa faaliyetinin muhtevası açıklanmaya çalışılmaktadır.

Telafer'deki mezhepçi inşa ve mezhep konsolidasyonu, ana hatlarıyla, devlet düzeyinde güvenlik güçleri ve devlet-dışı aktörler düzeyinde direnişçi gruplar ve aşiretler tarafından gerçekleştirilmiş, ABD işgal kuvvetlerinin yerel uygulamalarıyla kolaylaştırılmış ve ülkedeki siyasi atmosferin ürettiği mezhepçi imgeler, oluşan güvensizlik ortamı ve bölgedeki aşiret düzeni aracılığıyla sürdürülebilir kılınmıştır. Bir sonraki bölümde detaylı

17 Irak’taki mezhepçi siyasi atmosferin aksine sonuçlar ortaya çıkaran farklı anket çalışmaları içi bakınız: Michael Lipka, "The Sunni-Shia Divide: Where They Live, What They Believe and How They View Each Other", Pew Research Center, 18 Haziran 2014; "Many Sunnis and Shias Worry About Religious Conflict", Pew Research Center, 7 Kasim 2013; "Iraqi Worries and Hopes Regarding Sectarianism", Greenland Quinlan Rosner Research, 2011; Fotini Christia, Elizabeth Dekeyser and Dean Knox, "To Karbala: Survey in Religious Shi'a from Iran and Iraq", Massachusetts Institute of Technology, 2016; Mansoor Moaddel, Julie de Jong and Munqith Dagher, "Beyond Sectarianism in Iraq", Context, 2011, c. 10, sy. 3, s. 66-67; "Investing in Iraq's Peace: How Good Governance Can Diminish Support for Violent Extremism", Mercy Corps, 2015.

18 Popülerlik ile, mezhepçiliği aşağıdan yukarıya bir etkiyle sürdürülebilir ve var kılan ve topluluğun tamamını olmasa bile önemli büyüklükte kısmını içeren toplumsal destek ve inisiyatif, yani mezhepçi toplumsal tabanın genişliği kastedilmektedir. 
olarak tartışılacak olan Irak güvenlik güçlerinin, direnişçi grupların, Telafer aşiretlerinin ve ABD ordusunun Telafer'deki faaliyetleri; güç çatışmasını, güvensizliği, ittifak tercihlerini, mezhepsel kimlik konsolidasyonunu, mezhepçi normları ve popüler inşayı birçok noktada kesiştiren süreçlerde sebep ve sonuç olarak bir arada rol oynamıştır. Aynı zamanda, Telafer örneğinde aşiret düzeni, terör ortamı ve ABD'nin ve Irak devletinin yerel uygulamaları hem diğer aktörlerin içinde bulundukları ve mezhepçilik sürecini sürdürülebilir kılan bir bağlam/yapı hem de mezhepçiliğin yayılımını sağlayan birer fail (agent) olarak ortaya çıkmaktadır. Neticede, mezhepçilik, sadece belirli ilkelerin, değerlerin ve güç ya da çıkar odak11 rasyonel hesaplamaların sonucu olarak hazır bulunmaz, bahsedilenlerle alakalı olarak yatay ve dikey biçimde failleri sosyalleştirir, bu yönde sosyalleşmeye zorlar; mesela, bu sosyalleşmeye örnek olarak ileride detaylı olarak açıklanacağı üzere, fertler özünde aşiret rekabeti olan çatışmaları mezhep çatışması olarak görmeye başlayabilir. Bir sonraki bölümde, mevcut sosyo-politik olabilirlik yapıları (opportunity structures) içerisinde gerçekleşen bu yatay ve dikey inşa faaliyetleri gösterilecektir.

\section{Irak Türkmenlerinde Mezhepçilik: Bağlam, Süreçler ve Aktörler}

Birleşmiş Milletler Irak Destek Misyonu raporunda ${ }^{19}$ Irak'ın on beş ihtilaf11 bölgesi arasında gösterilen Telafer, Irak'taki diğer Türkmen bölgeleriyle kıyaslandığında birkaç nokta ile öne çıkmaktadır: Birincisi, ekonomik, sosyal ve mezhepsel problemleriyle en sorunlu Türkmen bölgesi olmasi; ikincisi, merkez nüfusu tamamen Türkmenlerden oluşan tek yerleşim bölgesi olması; üçüncüsü, Irak’taki en kalabalık Türkmen bölgesi olması; dördüncüsü, Sincar bölgesiyle birlikte Irak Kürdistan Bölgesel Yönetimi (IKBY) ve PKK'nın Suriye kolu olan PYD'nin (Demokratik Birlik Partisi) kontrolündeki Kuzey Suriye arasında bir tampon bölge konumunda olması; beşincisi, Türkiye ve Irak Türkmenleri ile Türkiye ve Iraklı Sünni Araplar arasında Kürdistan Bölgesel Yönetimi'nin kontrolünde olmayan tek koridor olması $;^{20}$ altıncısı ve bu çalışmanın ana teması bakımından en önemlisi, Türkmenler arasında mezhep çatışmasının kitlesel ve yoğun ola-

19 "UNAMI Submits its Reports on the Disputed Internal Boundaries", United Nations Iraq, 22 Nisan 2009.

20 Serhat Erkmen, "Unutulmuşluğun Karanlığından Umudun Aydınlığına Uzanan Bir Türkmen Kenti: Telafer", Ortadoğu Analiz, 2009, c. 1, sy. 5 , s. 7. 
rak yaşandığı tek Türkmen bölgesi olmasıdır. DAEŞ işgali öncesinde onlarca aşiretin yaşadığ yaklaşı 510 bin nüfuslu kentte ${ }^{21}$ Türkmen nüfusun Sünni-Şii dağılımı konusunda verilen oranlar farklılık göstermekte, yüzde 85-15 ile yüzde 50-50 aralığında değişen rakamlar sunulmaktadır. ${ }^{22}$

DAEŞ'e yönelik Musul operasyonu yerli ve yabancı medya unsurlarında Telafer'de mezhep çatışmasını gündeme getirmiştir. ${ }^{23}$ Ancak gelinen bu noktayı sadece DAEŞ'le özdeşleştirmek, bölgedeki mezhep çatışmasının anlaşılmasında açılayıcı olmayacaktır zira Telafer' de mezhep çatışmasının kısa ancak önemli bir geçmişi vardır. ${ }^{24}$ Zahiren çelişkili biçimde, mez-

${ }^{21}$ Bilgay Duman ve Feyzullah Tuna Aygün, "Telaferli Türkmen Göçmenlerin Durumu ve Telafer'in Geleceği”, ORSAM Rapor, 2017, sy. 215, s. 7.

22 Verilen oranlardan bazı örnekler için bakınız: Ümit Özdağ ve Nevin Yazıcı, "Irak’ta Direnen Bir Türkmen Kenti: Telafer”, 21. Yüzyll Türkiye Enstitüsü, 16 Haziran 2014; "Türkmenlerin Telafer Endişesi”, Türkiye Gazetesi, 9 Ağustos 2017; "Irak'ta Mezhep Kıyımı", Milliyet, 17 Haziran 2014; "Şii Milis Haşdi Şabi Telafer'e İlerliyor”, NTV, 3 Kasım 2016; “Ankara Türkmenler İçin Devrede”, Deutche Welle, 23 Haziran 2014.

23 Bu haberlerden örnekler için bakınız: "Telafer'den Göç Eden Türkmenler Türkiye Sınırına Ulaştı", Anadolu Ajansı, 5 Aralık 2016; Hassan Hassan, "The Battle for Mosul is a Struggle for Iraq Itself", The National, 16 Ekim 2016; "Fears of Sectarian Tension as PMUs Close in on Tal Afar", Al Jazeera, 25 Kasım 2016; "Tal Afar, West of Mosul, Becomes Center of Battle for Influence in Iraq", The New York Times, 29 Ekim 2016; "Isis is Full of Killers, the Worst Come from Tal Afar: Bitter Fight for City Ahead and the Ciolence May not End There", The Independent, 15 Kasim 2016; "Tal Afar Sunnis Oppose Shiite Hashd Forces Entering Their Town", Rudaw, 19 Kasim 2016; "Iraqi Shi'ite Fighters Mass Near Flashpoint Town West of Mosul", Reuters, 21 Kasim 2016; "Iraqi Battle for Mosul Prompts Fears of More Sectarian Violence", CNN International, 21 Kasim 2016; "ISIS Attempting to Stir Sectarian Hatred with Murals in Tal Afar, Iraq", Al Masdar, 21 Ocak 2017; "Iraq's Turkmen Mobilise for a Post-ISIL Future", Al Jazeera, 13 Şubat 2017.

24 Çalışmanın bu kısmında anlatılacak olan ve genel olarak yazılı literatüre ve katılımcılarla yapılan görüşmelerden elde edilen bilgilere dayanacak olan bu çatışma hikayesi, birkaç noktada sorunlarla karşılaşıyor: Birincisi, Türkmenlere yönelik Türkiye'deki ciddi kamuoyu ilgisine rağmen, özellikle Telafer'deki mezhep çatışmasına ilişkin yazılı kaynaklar yok denecek kadar azdır. Sorunun ne kaynaklarına ne gelişimine ne de spesifik olaylara ilişkin akademik çalışmalara neredeyse hiç rastlanmazken medyada da önemli bir yer tutmamıştır. İkincisi, Türkmen yazarların yazdıkları kitaplara ve makalelere bakıldığında konuya genel olarak temas edilmediği görülmektedir. Bu durum, Türkmenlerle ilgili çalışmaları büyük oranda milliyetçi Türkmenlerin yapması ve milliyetçi eğilimlerinden dolayı konunun gündemde pek fazla tutulmak istenmemesiyle açıklanabilir. Üçüncüsü, İngilizce kaynaklara bakıldığında, konunun büyük oranda Irak'taki direniş aktivitesi ve ABD'nin askeri varlığ 1 ve operasyonları çerçevesinde ele alındığ söylenebilir. Bu sebeple, oluşturulan literatür direniş aktivitesinin Telafer'deki yoğunluğuna ve ABD operasyonlarına dayanarak büyük ölçüde 2004-2005 yıllarına odaklanmıştır. Yine de İngilizce yayın yapan büyük ya da küçük ölçekli birçok haber sitesinde 2005 sonrası olaylara yönelik 
hepsel ayrılıklar ve çatışmalar, Telafer için görece olarak yeni olgulardır. Dahası, bazı vakalarda Telaferliler için mezhep bilincinin de çatışmasıyla hemen hemen eş zamanlı bir olgu olduğu söylemek mümkündür. ${ }^{25}$ Buna göre, 2000'lerden önce Türkmenler arkadaşlarının, akrabalarının, hatta kendilerinin mezhepleri konusunda ciddi anlamda fikir sahibi değildir. Mezhep bilinci konusunda Telaferli bir sığınmacının bahsettiği anı önemli bir örnek teşkil edebilir: "Birkaç sene evvel babam ameliyat oldu, Musul'da bir hastanede. Bir amcam hastaneye gelmedi, telefonla aradı. Ona 'Hastaneye niye gelmedin?' dedim. Dedi ki 'Ben Şii'yim, Musul'a gelirsem kim bilir başıma neler gelir!' Amcam Şii'ymiş, daha evvel bilmezdim". ${ }^{26}$ Öte yandan, mezhep kimliği konusunda Şii Türkmenlerle alakalı farklı bir durum daha vardır: Bugünkü Şii Türkmenlerin, orijinal olarak Bektaşi oldukları, süreç içerisinde Şiileştikleri ve 1940'lara kadar Telafer'de hiçbir Şii camisinin bulunmadığı ileri sürülmektedir. ${ }^{27}$ Mezhep çatışmasına yönelik ise, bu çalışmanın örneklemindeki katılımcıların yüzde 97'si Türkmenler arasında Sünni-Şii çatışmasının yeni bir olgu olduğunu ve Saddam Hüseyin'in düşüşünden sonra ortaya çıktığını belirtmiştir.

Telafer, mezhep çatışması noktasına nasıl ve neden geldi ve bölgede ne tür bir mezhep çatışması tecrübe edildi? Telafer'deki mezhep çatışması beş ana safhada gelişim göstermiştir. Bu safhalardan ilki ve en önemlisi Mart 2003-Ekim 2005 arasındaki hazırlık dönemidir ki bu bölümde en detay11 incelemeye tabii tutulacak olan periyottur. Irak'ın ABD liderliğindeki Çokuluslu Koalisyon Kuvvetleri tarafından işgalinden sonra, Telafer yerli ve yabancı birçok farklı direniş̧̧i grubun yerleştiği sorunlu bir bölge haline gelmişti. Özellikle, bölgeyi işgal eden ABD birliğinin 2004 yılının başlarında çekilmesinden sonra Telafer, merkezi yönetimden uzak oluşu, Musul gibi Sünni direnişin önemli merkezlerinden birisi haline gelen bir şehre yakınlığı ve Suriye sınırıyla bir geçiş bölgesi oluşturan konumu gibi sebeplerle el-Kaide gibi birçok direnişçi grubun yerleştiği stratejik bir müstahkem mevki olmuştu. Bu grupların bölgeye nasıl kolaylıkla yerle-

haberlere Türkiye ve Türkmen kaynaklarına nazaran çok daha fazla yer verilmiştir.

25 Suphi Saatçi ile mülakat, Mart 2016, İstanbul; Mehmet Tütüncü ile mülakat, Mart 2016, İstanbul; Kemal Beyatlı ile mülakat, Mart 2016, İstanbul.

26 Abbas Aziz ile mülakat, Şubat 2016, Ankara.

27 Duman, “Irak’ta Bir Kimlik Arayışı: Bektaşiler”, Ortadoğu Analiz, 2011, c. 3, sy. 35, s. 62 . 
şebildiği ve güçlerini konsolide edebildikleri konusunda üç temel iddia bulunmaktadır: Telafer'in kuzey mahallelerinde yaşayan yaklaşık 20 bin Baasçı Türkmen'in direnişçilere yardımcı olması, bölgedeki kuvvetli aşiret yapısının kullanılmış olması ve suikast ve benzeri yöntemlerle aşiretlerin zorlanması ve 1980'lerden beri bölgede varlık gösteren Vahhabi imamların etkisidir. $^{28}$

Özellikle Eylül 2004 ile Nisan 2005 arasındaki dönemde Telafer, direniş merkezi olarak neredeyse Felluce'nin yerini almış, ${ }^{29}$ Kuzey'in Felluce'si olarak anılmış, ${ }^{30}$ direniş hücrelerinin örgütlenme, eğitim ve teçhizatlandırma işleri için bir üs ve Suriye üzerinden gelen militanların ana geçiş noktası konumuna gelmiş, ${ }^{31}$ Telaferliler silah zoruyla baskı altına alınmıştı. ${ }^{32}$ 2005 y1lındaki bazı istihbarat raporları Irak'taki el-Kaide yapılanmasının lideri Ebu Musab el-Zerkavi'nin merkez üssünün Telafer olduğunu iddia etmiştir ${ }^{33}$ ki bu iddia Zerkavi gerçekten Telafer'de konuşlanmasa bile bölgedeki aktivitenin yoğunluğuna işaret etmektedir. Netice olarak bölgedeki direniş aktivitesi, ilki Eylül 2004'te Kara Tayfun Operasyonu'yla başlayan, en geniş kapsamlısı Nisan 2005'teki Hakların İadesi Operasyonu'yla (Telafer Savaşı) gerçekleştirilen, 2006 kışına kadar süren ve çok ciddi insani krize yol açan bir operasyonlar serisine yol açmıştı. ${ }^{34}$ ABD'nin Irak'taki

28 Travis Patriquin, "Using Occam's Razor to Connect the Dots: The Baath Party and Insurgency in Tal Afar", Military Review, 2007, c. 1, sy. 2, s. 18-22.

29 Jay B. Baker, "Tal Afar 2005: Laying the Counterinsurgency Groundwork", Army, 2009 , c. 6 , sy. 59 , s. 61-62.

30 Ferry Biedermann, "Tel Afer's Ethnic Tug of War Puts Iraq Army to the Test", Financial Times, 18 Ocak 2006.

31 Baker, s.62-63.

32 Bruce R. Pirnie and Edward O'Connell, Counterinsurgency in Iraq (2003-2006), CA: RAND Corporation, 2008, s. 39.

33 David R. McCone, Wilbur J. Scott, and George R. Mastroianni, "The 3rd ACR in Tal'afar: Challenges and Adaptations”, Strategic Studies Institute, 2008, s. 8.

34 Öncesi ve sonrasıyla operasyonlar hakkında bakınız: Bill Roggio, "Operation Restoring Rights in Tal Afar", The Long War Journal, 5 Eylül 2005; "Under Pressure, Rebels Abandon an Iraqi Stronghold", The New York Times, 12 Eylül 2005; John R. Ballard, Fighting for Fallujah: A New Dawn for Iraq, London: Praeger Security International, 2006; "Fear Casts a Shadow on 'Free City' Touted by Bush", Los Angeles Times, 26 Mart 2006; "Iraq: Challenges of Forced Displacement within Iraq," Internal Displacement Monitoring Centre, 2008; Anthony H. Cordesman and Emma R. Davies, Iraq 's Insurgency and the Road to Civil Conflict, Westport: Praeger Security International, 2008; Bilgay Duman, "ABD Güçlerinin 2004-2005 Operasyonları ve Bıraktığı İzler”, Ortadoğu Analiz, 2009, c. 1, sy. 5, s. 39-45; Jay B. Baker, "Tal Afar 2005: Laying the Counterinsurgency Groundwork", Army, 2009, c. 6, sy. 59, s. 61-68. 
en uzun yılları olarak bahsedilen bu dönem, $\mathrm{ABD}$ işgaline karşı direniş için önemi yanında, Telafer'de mezhepçiliğin temelinin atılması bakımından da önemlidir. Bu hazırlık döneminde yerel bağlamda geliştirilen yatay ve dikey inşa süreçlerinin mezhep kimlikleri ve mezhepçilik üzerindeki etkisi dört ana madde altında özetlenebilir ki bu süreçlerin birçoğu daha uzun y1llar devam edeceği için detaylı bir inceleme gerektirmektedir:

İlk olarak, bu dönemdeki Sünni direnişçi grupların aktivitelerinin mezhep farkındalığının artırılması yönünde önemi olduğu söylenebilir. Direnişçi gruplar, mücadelenin yalnız 'Amerikan-İslam mücadelesi' olmadığını aynı zamanda 'Sünni-Şii mücadelesi' olduğunu savunuyordu ve bölgeyi bazı yerel Sünni Türkmen topluluklarla elinde tutan bu gruplar birçok Şii Türkmen ailenin bölgeyi terk etmesine yol açacak sindirme kampanyası başlatmıştı. ${ }^{35}$ Öte yandan, direnişçi grupların bu pratikleri sadece Şiilere yönelik değildi, talimatlara uymayan herkes yaptırıma maruz kalıyordu. Mesela, polis olmak isteyen Sünni Türkmenler, direnişçilerin tehditlerinden dolayı polis gücüne geniş anlamda dâhil olamıyorlard.$^{36}$ Kentin Sünni belediye başkanı ise direnişçilerle iş birliği yapmaktayd1. ${ }^{37}$ Kısaca kent, mezhepçi grupların ve bunların dikey dayatmalarının hakimiyeti altındaydı.

İkinci olarak, Sünni Türkmenler, Irak polis ve askerinin ayrımcı pratiklerinin hedefi olmuştu. Telafer'in Sünnileri bölgedeki Şii komando birliğinin her Sünni'yi potansiyel suçlu olarak gördüğünden ve gözaltına aldığından şikâyet etmişti. Telafer'in Şii polis müdürü, göreve gelir gelmez önemli Sünni memurları görevden uzaklaştırmış ve Şii Bedir Tugayları'nın bölgede hâkim olacağına dair söylentiler yaymıştı. ${ }^{38}$ Güvenlik kuvvetleri içerisinde çoğunluğu Şiilerden oluşan polis birimi bir ABD askerinin ifadesiyle 'mezhepçi bir ölüm mangasından başka bir şey değildi' ve rakip aşiretlere ya da Sünnilere saldırı düzenlemek dışında konuşlandığı kalenin dışına çıkmıyordu. ${ }^{39}$ Öte yandan polislik, Şii Türkmenlerin bölgede yapabilecekleri tek ve 'en güvenli' iş haline gelmişti. Ancak polis olarak görev yapan

\footnotetext{
George Packer, "The Lesson of Tal Afar: Is It Too Late for the Administration to Correct Its Course in Iraq?", The New Yorker, 10 Nisan 2006.

36 Michael Fitzsimmons, Governance, Identity, and Counterinsurgency: Evidence from Ramadi and Tal Afar, PA: US Army War College Press, 2013, s. 88.

37 Ibid., s.83-84.

38 Ibid., s.92.

39 Ibid., s.83-84.
} 
pek çok Şii Türkmen, ailesinden veya aşiretinden birçok kişinin öldürüldügü kişilerdi. ${ }^{40}$ Mezhepçi gruplaşma açısından temsili olmasa da çarpıcı bir örnek, o dönem ABD'li bir gazetecinin Şii Türkmen bir polis memuruna Telafer'de kaç terörist ve terör sempatizanı olduğuna dair sorduğu soruya verdiği 150 bin sayısıdır ${ }^{41}$ ki yaklaşık olarak Telafer'deki Sünni Türkmen sayısına denk düşmektedir. Özetle güvenlik güçleri, mezhepçi bir güvensizliğin kaynağı olmuşlardı.

Üçüncü olarak, ABD'nin bu bölgede mezhepçilik konusunda temel etkisi direniş̧̧i grupların en ciddi toplumsal destek kaynağı olan askeri varlıklarıyla alakalıydı. Ayrıca, bölgeyi Şiileri kendilerine hedef seçmiş gruplardan temizlemeye çalışmak, bu gruplar içerisinde yer almayanlar arasında dahi ABD'nin Şiilerin hamisi olduğu ve Şiilerin ABD kuvvetleriyle iş birliği içerisinde olduğu imajını güçlendirdiği söylenebilir ve bu imaj direnişçi grupların sürekli olarak kullandıği söylemlerden birisi olmuştu. ${ }^{42} \mathrm{Ek}$ olarak, ABD kuvvetleri tarafından Irak ordusu ve polisi bünyesine büyük ölçüde zaten gönüllü oldukları için Şiilerin dâhil edilmesinin, Telafer'de de polis teşkilatında Sünni Türkmenlerden kalan boşluğun Şii Türkmenlerle doldurulmasının Sünniler tarafından savaşın bir kampını silahlandırmak olarak algılandığı söylenebilir. ${ }^{43}$ Bununla alakalı olarak, saha araştırması sırasında katılımcıların ifadelerine göre ABD kuvvetlerinin Sünni ve Şiileri dengelemek adına -mesela ortak polis gücü oluşturulması konusundayaptıkları mezhepsel ayrımlar, mezhepsel farkındalığı ve hoşnutsuzluğu artırmıştı. Kısaca, ABD ordusunun varlığı mezhepçi bir yayılım için gerekli imajın somut zeminini teşkil ediyordu ve kullandıkları ayrımlar mezhepçi bir patika bağımlılı̆ğ oluşturacak ve birçok noktada formelleşecekti.

Son olarak, Telafer'de mezhepçiliğin en önemli parametresi olarak bölgedeki aşiretler ve aşiret yapısı öne çıkmaktadır. Telafer'in başından beri kuvvetli olan aşiret yapısı, bazı Sünni grupların bazı Sünni aşiretlerle ve bazı Şii grupların bazı Şii aşiretlerle ittifak kurma yoluna gitmesine neden olmuş, ${ }^{44}$ kimi aşiret mensupları direniş gruplarına dâhil olarak saldırı ey-

\footnotetext{
40 Packer, "The Lesson of Tal Afar".

41 Ibid.

42 Patrick Cockburn, The Occupation: War and Resistance in Iraq, NY: Verso, 2006, s. 12.

43 Fitzsimmons, s.88.

44 Duman, s.41.
} 
lemlerinde yer almış, neticede birçok çatışma kan davası halini de almıştır ya da zaten kan davası olan çatışmalar mezhep üzerinden sürdürülmüştür. Diğer yandan, ABD kuvvetlerinin bazı aşiretlerle ortaklık kurma çabalarının, diğerlerinin prestij ve otoritesine zarar vermeyi amaçlayan bir iltimas olarak algılandığı ve bölgedeki diğer aşiretleri yabancılaştırdığı söylenebilir. ${ }^{45}$ İlk başlarda sadece Şii aşiretler ABD ordusuyla iş birliğine girmeyi tercih etmişti. Özellikle Şii Çolak aşiretinin direnişçilerin saldırılarından korunmak adına $\mathrm{ABD}$ ordusuyla iş birliği yapması ve birçok Şii aşiretin bu iş birliğinin etrafında toplanması durumu daha karmaşık hale getirmişti. ${ }^{46}$ Aşiretleri yabancılaştıran bir diğer husus ise kendi aşiretlerinden insanların gözaltına alınması, tutuklanması ya da öldürülmesi oluyordu. Ayrıca bazı aşiret reisleri, bu süreçte $\mathrm{ABD}$ ordusunu manipüle etmiş ve kişisel ya da aşiret kazançlarına göre ABD yardımlarını ve desteğini kullanmış, hatta ABD yardımları bu aşiret reisleri aracılığıyla zaman zaman direniş̧̧ilere ulaşmışt1. ${ }^{47}$ Mesela, 4 Haziran 2005'te gerçekleştirilen ve altmıştan fazla aşiret büyüğünün katıldığ1 toplantıyla ilgili bir ABD askeri, bu aşiret reislerinin direnişi bitirmekle ilgilenmediklerini, yalnızca ABD ordusunu birbirlerine karşı kan davalarını sürdürmek üzere kullanmaya çalıştıklarını iddia etmiştir; buna göre Şii aşiret reislerinin askeri operasyona daha istekli olmalarının nedeni de Sünni rakiplerine karşı daha avantajlı konuma geçme isteğiydi. ${ }^{48}$ Ancak bu durum aşiretlerce daha normatif bir düzlemde yansitıllyordu; mesela, ABD'li subayların Sünni ve Şii aşiret liderleriyle yaptığı görüşmelerde Şiiler Sünnileri teröristlerin varlığını hoş görmekle suçlarken, Sünniler kendilerinin sürekli olarak teröristlikle suçlandıklarından şikâyet ediyordu. ${ }^{49}$ Neticede, taraflar arasındaki rekabet ciddi bir güvensizliğe ve emniyetsizliğe dönüşürken mahallelerin mezhepsel ayrımları keskinleşmeye başlamıştı. Bu güvensizliğe bir örnek olarak Hakların İadesi Operasyonu sırasında, direniş aktivitesinin yoğun olduğu Saray Mahallesi'ndeki Sünni sivillerin güneydeki bir Şii mahallesi üzerinden tahliye edilmesi için yapılan görüşmelerde birçok Sünni Türkmen'in güvenlik kaygısıyla Şii mahallesinden geçmeyi reddetmesi, hatta bazılarının

\footnotetext{
45 Patriquin, s.23.

46 Ibid., s.23.

47 Ibid., s.23.

48 Fitzsimmons, s.85.

49 Packer, "The Lesson of Tal Afar".
} 
‘ölmeyi Şii mahallesinden geçmeye tercih edeceklerini' ve 'kötü insanları arıyorlarsa Saray Mahallesi'nde değil, güneyde bulabileceklerini' söylemeleri verilebilir. ${ }^{50}$

$\mathrm{Bu}$ bağlamlar içerisinde ilerleyen ikinci safha, hazırlık periyodunu takip eden Ekim 2005-Şubat 2006 arasındaki kısa süreli bir uzlaşma ve görece istikrar periyodudur. Hakların İadesi Operasyonu'yla Telafer, ABD'nin Irak'taki kontrgerilla harekâtları içerisinde 'temizle-tut-kur' ${ }^{51}$ olarak adlandırılan stratejiyle bir başarı hikayesi olarak anlatılmaktaydı. Direnişçi aktivitesinin, aşiret rekabetlerinin, gerilimlerin ve ayrımcılıkların kısmen devam etmesine rağmen gerçekten de direniş gruplarının işgalinin sona ermesi Telafer için ilk başta istikrar işaretleri vermişti. Ek olarak, polis gücüne Sünnilerin de dâhil edilmesine yönelik çabalar olmuş, Sünni ve Şii aşiret reisleri bir araya gelmeye başlamış, Telafer'in önde gelen aşiretleri olan Şii Çolaklar ve Sünni Ferhatlar arasındaki sorunlar çözülme belirtisi göstermiş, Şubat 2006'da Sünni ve Şii aşiret reisleri geniş bir uzlaşma toplantısı düzenlemiş ve kentin ortak idaresi konusunda tartışmalar yapmıştı. ${ }^{52}$

Üçüncü safha, birbiri ardına gerçekleşen olaylar neticesinde Şubat 2006' da başlayıp Şubat 2011'e kadar sürecek olan tırmanma ve yoğunlaşma periyodudur. Şubat 2006'da Samarra'da Şiilerin büyük kutsiyet atfettiği elAskeri Türbesi'ne el-Kaide'nin düzenlendiği saldırıdan sonra mezhepçi gerilim Irak'ın genelinde olduğu gibi Telafer'de de tırmanma işaretleri göstermişti. ${ }^{53} \mathrm{Bu}$ saldırıdan birkaç hafta önce ABD birliği bölgeden geniş ölçüde çekilmişti. Aslında Samarra saldırısının Telafer'e etkisi, Irak'ın bir bölgesindeki ciddi bir mezhepçi aktivitenin diğer bir bölgede sadece sembolik bir anlama sahip olmadığını göstermektedir. Saldırının ardından Sünni ve Şiiler arasındaki suikastların sayısı artmaya başlamış, bölgedeki el-Kaide varlığ 1 yeniden canlılık göstermiş, direnişçiler ABD ordusuyla iş birliği yapan Sünni ve Şiilere saldırılar düzenlemeye başlamış ${ }^{54}$ ve aşiretler arasındaki ilişkiler gerilmişti.

50 Fitzsimmons, s.93.

51 Sarah Sewall, John A. Nagl, David H. Petraeus and James F. Amos, The US Army/ Marine Corps Counterinsurgency Field Manual, Chicago: University of Chicago Press, 2007, s. 182-184.

52 Fitzsimmons, s.90, 104-105.

53 Ibid., s.90.

54 Peter Baker, “An Iraq Success Story's Sad New Chapter”, The Washington Post, 21 Mart 2006. 
Yeni kriz dönemin kırılma yaşadığı en ciddi yer, anket katılımcılarının Telafer'de mezhepçiliği tırmandıran esas nokta olarak belirttiği 27 Mart 2007'deki bombalı saldırı ve akabinde gerçekleşen olaylardır. Bir insani yardım kuruluşu tarafından gönderilmiş süsü verilen bir ekmek kamyonu Şii Türkmenlerin yoğun olarak yaşadığı bir mahallede patlatılmış, aynı gün içinde yine bir Şii mahallesindeki kalabalık bir pazar yerinde bomba yüklü bir araç infilak ettirilmişti. Olay gecesi, Şii polis güçleri ve maskeli silahlı gruplar Sünni bir mahalle olan el-Vahada'ya Mehdi Ordusu'na bağl1 Şii militanların da dahil olduğu iddia edilen bir baskın yapmış, ${ }^{55}$ rastgele evlerden çıkardıkları Sünni Türkmen erkekleri sokakta öldürmüşlerdi ${ }^{56}$ ve Telafer'in polis gücü içerisindeki Sünni Türkmenler kovulmuş, yerlerine Şii Türkmenler getirilmişti. ${ }^{57} \mathrm{Bu}$, Telafer'de Şiilerin yaptığ 1 ilk büyük misillemeydi ve bundan sonraki y1llar karşıllklı misillemelerle geçecekti. Mesela, benzer bir olay 8 Ağustos 2008'de yaşanmış, Şii mahallesindeki bir sebze halinde bomba yüklü bir kamyon patlatılmış, eylemin ardından Şii siviller polislerle birlikte Sünnilere saldırmıştı. ${ }^{58}$ Artan gerilim, şiddet olayları ve tehditler sonucunda kentin belediye başkanı ve polis müdürü olan Necim el-Cuburi (Musullu Sünni Arap ve eski Baas partili), Eylül 2008'de güvenlik kaygılarını belirterek kenti terk etmişti ki Cuburi 2005 baharında Telafer polis müdürlüğü görevini aldığında kendinden önceki altmış kişi bu görevi reddetmişti. ${ }^{59}$ Ayrıca, yaşanan çatışmaların bölge üzerindeki etkisini göstermesi bakımından, ABD'nin Irak'1 işgalinden önce 3,488 işyeri olan şehirde 2007 itibariyle 221 işyerinin açık kaldığının belirtilmesi temsili nitelikte olacaktır. ${ }^{60} \mathrm{Bu}$ güvensizlik ortamında, akamete uğramış uzlaşma teşebbüsleri de görülmüştü. Mesela, uzlaşma çabalarına öncülük etmeye çalışan Telaferli iki aşiret reisi 9 Haziran 2008'de silahlı saldırıya uğrayarak hayatlarını kaybetmişti. ${ }^{61}$ Ayrıca, katılımcılar uzlaşma çabalarının ‘içeriden ya da dışarıdan' tehditlerle sürekli sekteye uğradığını belirtmiştir.

\footnotetext{
55 “Iraq: Sunnis versus Shia in Tal Afar”, Stratfor, 29 Mart 2007.

56 James Cogan, "Iraq: US Occupation Sets off Sectarian Atrocities in Tal Afar", World Socialist Web Site, 30 Mart 2007.

57 Cordesman and Davies, s.564.

58 “US Drawdown Raises Security Fears in Iraqi City”, USA Today, 17 Ağustos 2008.

59 "Another Success? Iraqi Mayor Bush Once Hailed Flees to U.S.", McClatchy Newspapers, 30 Ekim 2008.

60 Ferai T1nç, “Türkmen Gözüyle Telafer”, Hürriyet, 20 Nisan 2007.

${ }_{61}$ 'Sheiks' Deaths Lead to Questions on Progress", Stars and Stripes, 12 Haziran 2008.
} 
Dördüncü safha, terörist saldırılar, aşiretler arası rekabetler, misillemeler ve ayrımcı politikalar çerçevesinde süren mezhep çatışmasını durdurmaya yönelik Türkiye'nin öncülügüüle gerçekleştirilen bir girişimle Şubat 2011'de başlayan yumuşama periyodudur. 24 Şubat 2011'de, 47 aşiret reisinin ve Telaferli iki milletvekilinin (Taki el-Mevla ve Nebil Harbo) katıldığ1 ve dönemin Başbakanı Recep Tayyip Erdoğan ve Dışişleri Bakanı Ahmet Davutoğlu'nun nezaretinde Türkiye'de düzenlenen toplantıda gruplar arasında uzlaşma ve çatışmanın çözümü tartışılmıştı. ${ }^{62}$ Telafer Ulusal Barış Komisyonu olarak adlandırılan kurul, bir sonuç bildirgesi yayınlayarak Telafer'in Sünni ve Şiilerine karşı işlenen tüm suçları kınamış, her türlü şiddeti -özellikle mezhepçi şiddeti- reddetmiş, herhangi bir suçtan sorumlu tutulanların aileleri ya da aşiretleri tarafından korunmayacağına ve kamu ve güvenlik hizmetlerinde gruplar arasında adil bir dengenin sağlanacağına dair söz vermişti. ${ }^{63}$ Şii Türkmen milletvekili Taki el-Mevla, 2012'de bir söyleşide, bu uzlaşma girişimlerinin sonuç vermeye başladığının ve Sünni ve Şii aileler arasında evliliklerin yeniden görüldüğün altını çizmişti. ${ }^{64}$ Katılımcılara göre de Şubat 2011'de başlayıp Haziran 2014'e kadar sürecek olan bu yumuşama periyodunda mezhepçi saldırılar ciddi oranda azalmıştı.

Beşinci ve son safha, 2014 Haziran ayında DAEŞ'in önce Musul'u, bir hafta sonra da Telafer'i işgal etmesiyle başlayan dağılma ve belirsizlik periyodudur. Şii Türkmen ailelerin büyük çoğunluğu Irak'ta Şiilerin çoğunlukta olduğu bölgeler olan Necef, Kerbela ve Hille'ye sığınmak zorunda kalırken, birçok Sünni Türkmen Türkiye'ye, Irak’ta Peşmerge kontrolündeki bölgelere ve Kerkük yakınlarındaki Yahyava mülteci kampına sığınmıştır. ${ }^{65}$ Telafer'de kalan 50-100 bin Sünni Türkmen de DAEŞ'e karşı Musul operasyonuyla birlikte bölgeyi terk etmiştir. ${ }^{66}$ 2017'nin Ağustos ayında bölgenin DAEŞ’ten temizlenmesinin ardından bölgedeki düzeni

62 “Telafer'e Dokunan Türkiye’ye Dokunur”, Hürriyet, 26 Şubat 2011.

63 Duman, “Türkiye'den Irak’a Uzanan Birlik Köprüsü: Telafer”, ORSAM, 3 Mart 2011.

64 Duman, "Taki el-Mevla ile Türkiye-Irak İlişkileri Sohbetleri”, ORSAM, 18 Haziran 2012.

65 Duman, "Saha Gözlemleri Işı̆ğında Necef ve Kerbela'da Yaşayan Telaferli Göçmen Türkmenlerin Durumu", Ortadoğu Analiz, 2017, c. 9, sy. 79, s. 58.

66 “Telafer'i DEAŞ’tan Kurtarma Operasyonu Başladı”, CNN Türk, 20 Ağustos 2017; “Telafer'de Operasyon Başladı", Milliyet, 21 Ağustos 2017; "Irak Ordusu Telafer'in Dış Mahallelerine Ulaştı”, NTV, 22 Ağustos 2017. 
etkileyecek üç temel etkenin bulunduğu söylenebilir: Birincisi, bölgeden göç etmek zorunda kalan Sünni ve Şii Türkmenlerin geri dönüşünün nası1 sağlanacă̆ı; ikincisi, Haşdi Şaabi'nin bölgedeki hakimiyetinin özellikle Sünni Türkmenlerde oluşturduğu korku; ${ }^{67}$ üçüncüsü, hem Sünni hem Şii Türkmenlerin DAEŞ işgali süresince yaşadıkları sıkıntılar ve bölgeye dönmeleriyle karşılaşacakları manzaradır. Mesela, bölgedeki Haşdi Şaabi birliğinin Sünni Türkmenlerin geri dönüşüne zorluk çıkarması durumunda ya da DAEŞ'e katılmış Sünni Türkmenlerin ve DAEŞ tarafindan yıkılan Şii camilerinin geri dönüş sürecinde birer propaganda aracına dönmesi halinde misillemeleri yönlendirecek bir çatışma zemininin oluşacağı söylenebilir.

\section{Anket Sonuçları ve Çıkarımlar}

Bu bölümde, yukarıda bağlamı, süreçleri ve aktörlerinin anlatıldığı mezhep çatışmasının Telafer Türkmenlerini nasıl etkilediğine, Telafer Türkmenleri arasında mezhep kimliğinin ve mezhepçiliğin hangi boyutlarda olduğuna yönelik anket çalışmasının ve görüşmelerin sonuçları aktarılacaktır. Anket çalışması, 2 Şubat-15 Nisan 2016 tarihleri arasında, 2014 Haziran'ından itibaren DAEŞ işgalleri sebebiyle Telafer'den kaçıp Türkiye'ye sı̆̆ınmak zorunda kalan Sünni Irak Türkmenleri arasında Ankara'da Türkmenevi Yardım Merkezi, Türkmenevi Sağlık Merkezi ve sığınmacıların evlerinde yazar tarafindan yüz yüze uygulanmıştır. 180 kişiye uygulanan ve kapalı uçlu sorular içeren anketin yanı sıra, katılımcılarla ilgilendikleri konularda yapılandırılmamış mülakatlar gerçekleştirilmiştir. Çalışmanın örneklemi, kartopu ve amaçlı örnekleme yöntemleriyle oluşturulmuştur. Çalışmanın ana temasına ilişkin bulgular altı ana madde altında incelenebilir: ${ }^{68}$

İlk olarak, örneklem içerisinde Şiilerin olmaması mezhepçilik konusunda bazı noktalara ışık tutmaktadır: Katılımcılara Şii Türkmenlerin Türkiye'ye neden gelmediği sorulduğunda üç temel iddia öne çıkmaktadır: Birincisi, Şii Türkmenlerin Irak'ın Şii bölgeleriyle ve topluluklarıyla aralarındaki

67 Duman ve Aygün, “Telaferli Türkmen Göçmenlerin Durumu ve Telafer'in Geleceği”, s. 8.

68 Bu noktada, bulgularla alakalı yapılmış olan her bir çıkarımın çalışma örnekleminden hareketle Telafer hakkında ulaşılması muhtemel sonuçlar olduğu, ancak genellemeler yapabilmek için farklı dönemlerin ve grupların karşılaştırmalı verisine ihtiyaç duyulduğu göz önünde tutulmalıdır. 
mezhepsel ayniyet sebebiyle eskiden beri daha yakın olduğunu iddia etmektedir. İkincisi, Şii Türkmenlerin, Türkiye'nin Sünnilerin çoğunlukta olduğu bir ülke olması sebebiyle Türkiye'de kendilerine karşı mezhepsel baskı oluşabileceğinden korktukları için Türkiye'ye gelmemeyi tercih ettiklerini ileri sürmektedir. Üçüncüsü, Türkiye'nin Sünni Türkmenlere aşırı derecede odaklanarak ve Şii Türkmenleri ihmal ederek onları yabancılaştırdığını savunmaktadır. Sonuç olarak, Şii Türkmenlerin DAEŞ işgalleri sonrasında sığındıkları bölgelerde (büyük oranda Necef ve Kerbela'da) yaşadıkları dışlanma ve ayrımcılık sorunlarına dair işaretler bulunsa da ${ }^{69}$ katılımcıların iddiaları, Sünnilerin perspektifinde Türkiye ile Şii Türkmenler arasında (potansiyel ya da aktif) bir mezhepsel gündeme dair ipucu vermektedir.

İkinci olarak, anket çalışması mezhep çatışmasının yoğunluğu konusunda fikir vermektedir: Irak'ta yaşadığı bölgede Türkmenler arasında mezhep çatışmasına bizzat ne kadar sık şahit olduğu sorusuna katılımcıların yüzde 48'i çok sık cevabını verirken, yüzde 16'sı slk cevabını vermiştir. Katılımcıların yüzde 13'ü mezhep çatışmasına zaman zaman şahit olduğunu söylerken, yüzde 10'u nadiren şahit olduğunu, yüzde 13'ü ise hiç şahit olmadığını ileri sürmüştür. Görüldüğü üzere, örneklemin büyük çoğunluğu yoğun bir mezhep çatışması hafızasına sahiptir. Katılımcıların farklı mahallelerden ve aşiretlerden seçilmesine dikkat edildiği düşünülürse, bu sonuç çatışmanın kapsamını göstermektedir. Öte yandan, katılımcıların yüzde 87'si mezhep çatışmasının Türkmenleri böldügünü düşünmektedir ki bu, bölgedeki çatışmanın yok sayılamayacak kadar ciddi bir olgu olduğunu göstermektedir. Bahsedilen bu iki bulgunun, Telafer' deki mezhep çatışmasının niceliğine ve niteliğine dair önemli birer delil oldukları söylenebilir.

Üçüncü olarak, katılımcıların mezhebe ve mezhep kimliğine nasıl baktıklarına dair sonuçlar mezhepsel farkındalık ve aidiyet konusunda bulgular sunmaktadır: Katılımcıların yüzde 85 'i mezhebini çok önemli görürken, mezhebinin önemli olmadığını düşünenlerin oranı yalnızca yüzde 10 'dur. Bunun ciddi bir mezhepsel sahipleniş olduğu söylenebilir. Ancak bu sonuç, hayatın mezhep kurallarına sürdürüldüğünü iddia etmez; mezhep kimliğiyle özdeşleşmeyi, bu kimliğin içselleştirilmesini ifade eder. Diğer bir bulgu,

${ }^{69}$ Duman, "Saha Gözlemleri Işığında Necef ve Kerbela'da Yaşayan Telaferli Göçmen Türkmenlerin Durumu”, s. 58. 
katılımc1ların yüzde 98'inin mezhebinden asla vazgeçmeyeceğini söylemesidir ki burada mezhebini önemli görmeyenlerin büyük çoğunluğunun da cümleyi onayladıkları görülmektedir; dolayısıyla mezhebin sadece ilkesel ya da pratik kurallar olarak kişilerin hayatında bulunmadığı, ayrıca kültürel bir varlık olarak toplumda yer aldığı söylenebilir. Ek olarak, katılımcıların yüzde 93'ü mezheplerini değiştirmeleri durumunda yakın çevrelerinden ciddi tepki alacağını düşünmektedir ki yine mezhep olgusunun toplumdaki yerleşikliğini göstermektedir. Diğer taraftan, katılımcıların mezhep kimliğini diğer kimliklerin yanında nasıl değerlendirdiğine bakılacak olursa, örneklemin üçte biri mezhep kimliğini kendilerini tanımlamada en çok önem verdikleri üç kimlik boyutundan biri olarak sunmuştur. Kat1lımcıların çok büyük çoğunluğu ilk önceliği yalnızca Müslüman kimliğine verirken, ikinci öncelikler arasında mezhepsel kimlik etnik kimliği takip etmiştir. $\mathrm{Bu}$, ciddi bir mezhepsel farkındalık olarak değerlendirilebilir. Neticede, Irak Türkmenleri arasında mezhebin 2003 öncesi dönem için 'göz ardı edilebilir' bir boyut olduğuna dair iddialar düşünülürse, kısa bir dönem içerisinde gerçekleşen mezhepsel inşanın boyutları görülebilmektedir. $\mathrm{Bu}$, çatışmanın tarihinden de anlaşılacağı üzere, sadece bireylerin Irak'taki mezhepçi temayüllerden etkilenerek kendi tercihlerinin sonucu olarak ortaya çıkmış bir durum değildir; aksine, bireyler yaşadıkları bölgede ve ülkede gelişen mezhepçilikten dolayı buna zorlanmışlardır.

Dördüncü olarak, katılımcıların mezhepsel ayrıma dayanan pratikleri mezhepçilik konusuna 1şık tutmaktadır: Öncelikle, yüzde 63'lük bir oranla katılımcıların çoğunluğu, arkadaşlarının büyük çoğunluğunun ya da hepsinin Sünni olduğunu belirtmiştir. Bu çoğunluk ele alınacak olursa, bahsedilen durumun sadece kendi tercihlerinin sonucu olmadığı, yaşadıkları bölgelerin Sünnilerden oluşmasıyla alakalı olduğu söylenebilir. Ancak bu durumda da yaşadıkları bölgenin Sünni-Şii hatlarıyla bölündüğü düşünülebilir. Telafer, Sünni kuzey ve Şii güney olarak genel anlamda bölünmüş durumdaydı ancak Sünni ve Şiilerin bir arada yaşadığı bölgeler, aynı aşiretten oldukları vakalar göz önüne alınırsa bunun mutlak bir bölünme olduğu söylenemez. Diğer taraftan, arkadaşlarının en az yarısı Şiilerden oluşanların oranının yüzde 37 olduğu düşünülürse mezhepçi pratikleri tatbik etmeyen önemli bir kesimin varlığı onaylanmış olur. Öte yandan, katılımcıların yüzde 78'si Şiilerle arkadaş olmakta bir sakınca görmediğini belirtmiştir ki bu oran arkadaşlarının tamamı Sünnilerden oluşan yüzde 35'lik kesim düşünüldüğünde bölgeler arasında mezhepçi bir bölünmenin varlı̆̆ını bir 
dereceye kadar onaylar zira önemli bir kesim Şiilerle arkadaş olmakta bir sakınca görmese de arkadaş olma imkanına sahip olamamıştır. Ayrıca, Şiilerle arkadaş olmayı sorunlu görmeyenlerin yüksek oranı, mezhepçiliğin toplumun çoğunluğuna hâkim olmadığına işaret etmektedir. Öte yandan, katılımcıların yüzde 60'1 akrabaları arasında Şiilerin bulunduğunu ifade ederken, yüzde 40'ı hiçbir akrabasının Şii olmadığını beyan etmiştir. Şii akrabaları bulunanların çoğunluğu teşkil etmesi mezhepçiliğin çoğunluğa hâkim olmadığını söylese de Şii akrabası bulunmayanlar da önemli bir kesim oluşturmaktadır ve mezhepçi pratiklerin yoğun tatbiki konusunda fikir vermektedir.

Beşinci olarak, katılımcıların Sünni ve Şii Araplar arasında ayrım yapıp yapmadığı mezhepçilik için önemlidir: Katılımcıların Sünni ve Şii Araplarla komşuluğa ve evliliğe nasıl baktıklarına ve bu gruplara güvenlerine yönelik sorularda çoğunluk, Sünni Araplar hakkında olumlu görüş bildirmişken, Şii Araplardan yana olumsuz bir tavır ortaya koymuştur. Katılımc1ların Sünni ve Şii Araplara bakışı kıyaslandığında, Sünni Araplara yönelik yüzde 24-36 aralığında değişen daha olumlu bir bakış söz konusudur. $\mathrm{Bu}$, direkt olarak mezhepsel bir olumlama/olumsuzlama anlamına gelmektedir. Burada dikkat edilmesi gereken nokta, katılımcıların yaşadıkları bölge düşünüldüğünde Sünni Araplarla coğrafi olarak yakın olmalarına rağmen bu bölgelerde hemen hemen hiçbir Şii Arap yerleşimi bulunmamasıdır. ${ }^{70}$ Başka bir deyişle, Şii Araplarla ilgili fikirleri neredeyse tamamen dış etkilerle şekillenmiştir. Bu negatif tutumun, Şiiler ve Sünniler arasında varsayılan 'doğal ve verili' tarihsel ve doktriner düşmanlık sebebiyle ortaya çıktığı iddia edilemez zira bu argüman Şii Türkmenlerle Şii Araplar arasında da bir fark gözetmeyen üstün bir mezhep kimliği ön kabulüne dayanır ki pratiğin öyle olmadığı aşağıda görülecektir. Tarihsel düşmanlık argümanı yerine mevcut siyasi atmosferin oluşturduğu mezhepçi imgeler daha açılayıcı görünmektedir.

70 Irak'ın kuzeyinin etnik ve mezhepsel kompozisyonuna dair bir harita için bakınız: Crispin Smith, "What will a Future Kurdish State Do with its Own Minorities?", Middle East Institute, 6 Eylül 2017. 
Tablo 1: Sünni ve Şii Araplara güven oranı

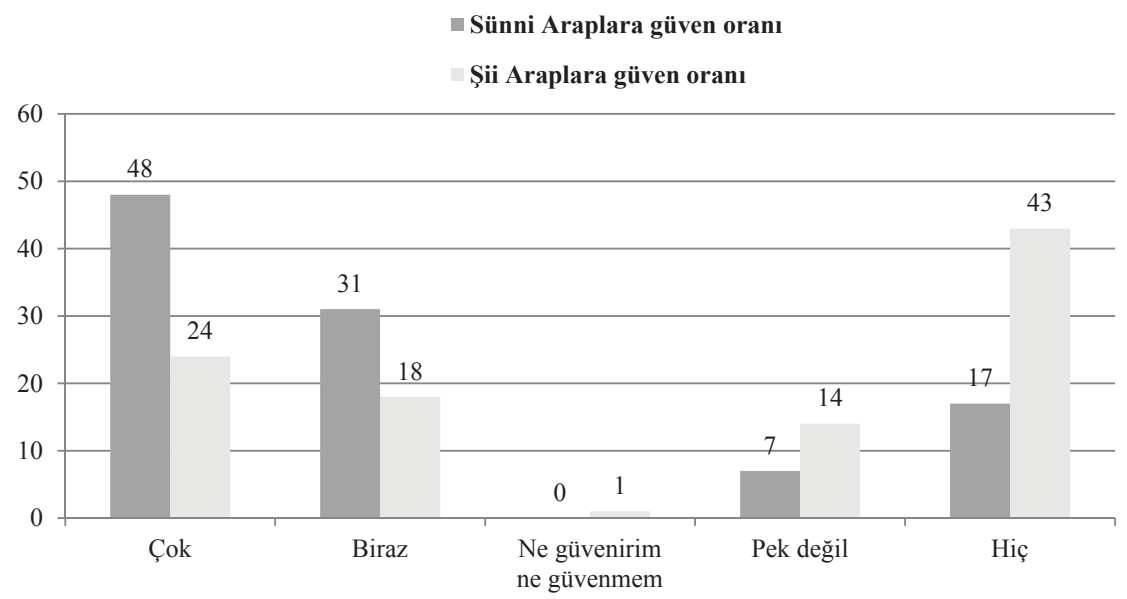

Tablo 2: Sünni ve Şii Araplarla evliliğe bakış

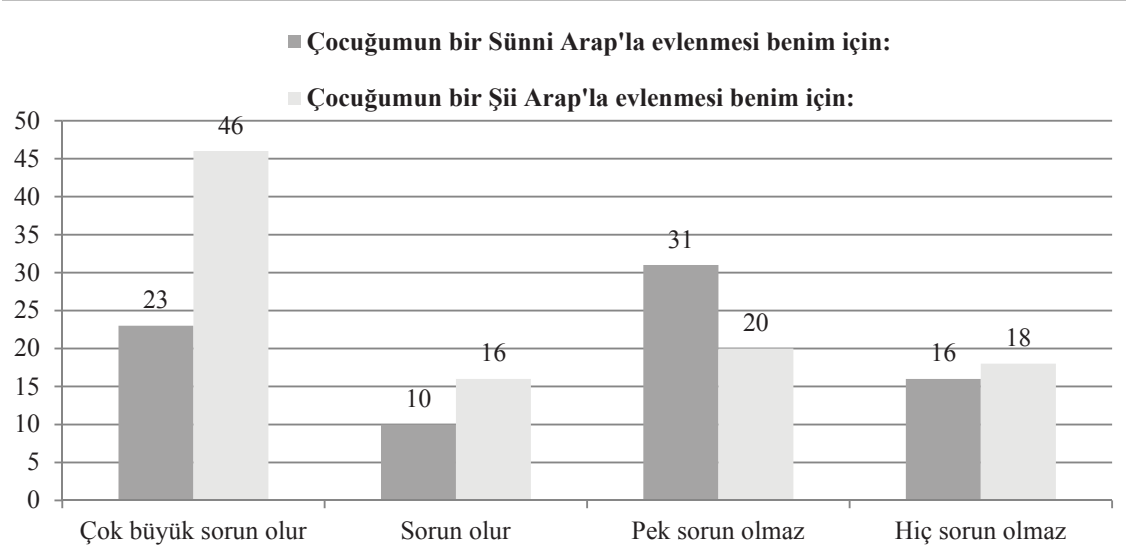

Altıncı olarak, Sünni ve Şii Türkmenler arasındaki ilişkiler mezhepçi eğilimlerle alakalı en çok fikir verecek husustur: Öncelikle, katılımcıların yüzde 79'u Şii Türkmenlerle komşu olmakta bir sakınca görmediğini söylerken, yüzde 21'i Şii Türkmenlerle komşu olmak istemediğini belirtmiştir. Mahallelerin Sünni-Şii hattında ayrılma temayülü gösterdiği Telafer gibi yerler için bu oran önemlidir. Yaşam bölgesinde yoğun bir mezhep 
çatışması atmosferine maruz kalmış bir örneklemin katılımcılarının büyük çoğunluğunun 'karş1 mezhep grubu' ile hala bir arada yaşama isteği gösterdiği görülebilmektedir. Bu durum, mezhepçiliğin popülerliğini yanlışlamaktadır. Diğer taraftan, katılımcıların yüzde 51'i Şii Türkmenlere çok güvendiğini belirtirken, yüzde 20'si güvendiğini, yüzde 17'si pek güvenmediğini, yüzde 12'si hiç güvenmediğini belirtmiştir. Buradan iki farklı sonuç çıkarılabilmektedir: Birincisi, Şii Türkmenlere güvenmeyenlerin oranının Şii Türkmenlerle komşu olmak istemeyenlerin oranından az da olsa daha yüksek olduğu düşünülürse, bazı katılımcıların Şii Türkmenlere güvenmese de bir arada yaşamak konusunda istekli olduğu düşünülebilir ki bu da mezhepçiliğin ve 'karşı mezhep grubu' imgelerinin geri plana atılabileceğini göstermektedir. İkincisi, katılımcıların Sünni Araplara güven oranının Şii Türkmenlere güven oranından az da olsa daha yüksek olması dikkat edilecek bir husustur zira burada mezhepsel yakınlık etnik yakınlığ öncelemektedir. Diğer taraftan, Şii Türkmenlerle evlilik meselesi mezhep grupları arasındaki pratikler bakımından daha zorlayıcı görünmektedir: Katılımcıların yüzde 41'i çocuklarının Şii Türkmenlerle evlenmesini az ya da çok sorunlu olarak görürken, yüzde 32'si böyle bir evliliğin pek sorunlu olmadiğııı düşünmekte ve yalnızca yüzde 27'si böyle bir evlilikte hiçbir sakınca görmemektedir.

Bu bölüm, bir önceki bölümde anlatılanlardan ve başka bir çıkarımdan hareketle kapatılabilir: Kan davası çatışmaları ve mezhep ve aşiret çatışmalarının birbirine gömülü olması durumu (özellikle özünde aşiret çatışması olan bir gerilimin Sünni ve Şii aşiretler arasında yaşandığı için mezhep çatışması olarak görülmesi) anlaşılmadan en azından Telafer vakasında mezhep çatışması açıklanamayacaktır. Görüldüğü üzere ABD askeri notları, bölgedeki çatışmanın aşiret boyutuna dikkat çekerken, katılımcılara yaşadıkları bölgedeki aşiret çatışmasının sıklığı sorulduğunda mezhep çatışmasına oranla çok daha az görüldüğüne yönelik cevaplar alınmıştır: Yalnızca yüzde 26, yaşadığı bölgede aşiretler arası çatışmaya sık ya da çok sık şahit olduğunu ifade ederken, geri kalan yüzde 74'lük kesim bölgelerinde aşiret çatışmasının ya hiç olmadığını ya da çok nadiren veya bazen görüldüğünü iddia etmektedir. Yukarıda belirtildiği üzere, katılımcıların yüzde 64 'ü Türkmenler arasında mezhep çatışmasına sık ya da çok sık şahit olduğunu ifade etmiştir. ${ }^{71}$ Aslında, iki süreç birbirini sürekli olarak beslemiştir:

71 Sosyal düzenin olaylara nasıl etki ettiğini göstermesi bakımından bir katılımcının (Rıza, 61) anlattığı örneğe bakmak yeterli olacaktır: Sünni Hayyo aşiretine mensup 
mezhepçiliğin aşiretselleştirilmesi ve aşiretçiliğin mezhepselleştirilmesi. $\mathrm{Bu}$ noktada, mezheple iç içe siyasi imgelerin olayları yorumlamadaki etkisi de görülmektedir zira olayların bu kadar kolay bir şekilde mezhepçi gündem içerisinde ele alınmasının en önemli katalizörü bu imgelerin hazır bulunmasıdır. Aktörler, imgeler ve sosyal düzen tarafından sürekli olarak yeniden inşa edilen bu cebri mezhepçilik, insanları belli bir yönde hareket etmeye yönlendirmekte ya da zorlamaktadır.

\section{Sonuç}

Bu bölümde, elde edilen bulgulardan ve çizilen çerçevelerden yola çıkılarak Telafer, Irak ve Orta Doğu'da mezhepçiliğe yönelik daha geniş çıkarımlarda ve önerilerde bulunulacaktır, ancak genellemeler yapılabilmesi için farklı yerel bağlamların karşılaştırılmasının gerektiği not düşülmelidir. Bu noktada, en az dört temel başlığın öne çıktığı söylenebilir: Birincisi, Telafer'deki mezhepçiliğin evrimidir. Mezhepçiliğin inşasını ve çoklu kimliklerle karşılıklı etkileşimini gösteren Telafer vakasının DAEŞ sonrası geliştirilecek olan süreçlerle nasıl bir dönüşüm yaşayacağı büyük oranda aşiretler arasındaki (özellikle DAEŞ'e katılmış Sünni Türkmenler hakkındaki) müzakerelere, bölgede gerçekleştirilmesi muhtemel DAEŞ eylemlerine ve bölgeyi temizleyen ve kontrol altında tutan silahlı güç olarak Haşdi Şaabi'nin uygulamalarına bağlı olacaktır. Bahsedilen şartlara bağımlılık, mezhepçiliğin inşası hususuna tekrar işaret etmekle birlikte aynı zamanda yap1 sökümünün de mümkün olabileceğini haber vermektedir.

İkincisi, giriş bölümünde bahsedildiği üzere farklı yerelliklerin öz-imgeler ve öteki-imgeleri oluşturmadaki etkisidir. Başka bir deyişle, Telafer, Bağdat, Diyala ya da herhangi bir bağlamdaki mezhepçilik, kendi yerel bağlamlarını aşarak ülke ya da bölgedeki Sünni ve Şiilerin birbirleri hakkındaki genel bilgi ve algılarını üreten süreçler olarak çalışabilmektedir. Mesela, bu çalışmanın örneklemindeki katılımcıların Irak'ın Sünnilerinin yaklaşık yarısının ve Şiilerinin yarısından fazlasının birbirine düşman olduğunu düşünmesi bir gözlem değildir ancak bu imgelerle oluşturulmuş bir varsayım-

bir Türkmen, bir örgüte katılır ve Şii Çolak aşiretinin mahallesine bir bombalı saldırı düzenler; Çolak aşireti Hayyolardan sorumlunun kendilerine verilmesini ister ancak aşiretin davranış kodları rakip aşirete kendi mensubunu teslim etmeye izin vermez ve olay kitleselleşir ki kitleselleşirken mezhep kodları aşiret kodlarıyla birlikte çalışır. 
dır. Bu şekilde, farklı yerellikler arasında doğrudan bir nedensellik olduğu iddia edilemese de aralarındaki ilişkinin sembolik olduğunu söylemek de mümkün değildir. Dolayısıyla, farklı bağlamlarda gelişen mezhepçi aktivitelerin birbiriyle ilişkisini sadece olgular üzerinden (mesela misillemeler, bölgesel örgütler vb.) kurmak açıklayıcı olmayacaktır.

Üçüncüsü, teorik yaklaşımların farklılaşmasında en önemli hususlardan birini teşkil eden istikamet meselesidir. İlkçi yaklaşımlar mezhepçiliği verili anlamda hem yukarıdan 'arz edilen' hem de aşağıdan 'talep edilen' bir olgu olarak alırken, araçsalcılar sadece yukarıdan aşağıya etkiye odaklanmaktadır. İnşacı yaklaşımın ışığında ise Telafer'de verili olmayan yatay ve dikey inşa süreçleri ve değişkenleri görülebilmektedir. Aslında Telafer'deki mezhepçilik, daha önce bahsedilen dört ana unsurun (direnişçi gruplar, güvenlik güçleri, $\mathrm{ABD}$ ordusu, aşiretler) birbirleriyle ve kendi içlerinde yatay ve dikey ilişkileriyle ortaya çıkmış ve bu etkenlerden özellikle birisinin (aşiretler ve aşiret düzeni) varlığıyla etkisini devam ettirebilmiş bir vaka olarak görünmektedir. Telafer'in bu durumu, ilk bakışta, Sünni Arap aşiretlerinin ve militan örgütlerin kuvvetli olduğu Anbar ve Musul gibi vilayetleri andırmaktadır. Özellikle Nuri el-Maliki’nin 2006-2014 yılları arasındaki başbakanlık döneminde Irak güvenlik güçlerinin bu bölgelerdeki 'Sünni karşıtı' uygulamaları dikkate alındığında bu benzerlik dairesinin çapı genişlemektedir. Diğer taraftan, hem Sünni bölgelerdeki mezhepçiliğin Şii bölgelerdeki izdüşümü hem Şii hakimiyetindeki hükümetlerin ve Şii militan örgütlerin Şii kimliğini ve toplulukları konsolide etmeye yönelik faaliyetleri Şiiler arasında mezhepçiliğe Telafer'e benzer bir istikamet çizmektedir.

Bir yerel bağlam olarak Telafer'in ülke ve bölgesel bağlamdaki mezhepçiliğe yönelik söyleyebileceği bir diğer husus analiz birimi meselesidir. Üçüncü bölümde anlatılan mezhepçi aktiviteye bakıldığında en az dört temel analiz biriminin öne çıktığı görülecektir: uluslararası (devletler/toplumlar arası tabaka), devlet (resmi tabaka), devlet-dışı aktörler (orta tabaka) ve toplum (popüler tabaka). Mezhepçilik, en azından Telafer vakasında, birbiriyle bağlantılı bu dört tabakada farklı formlarda ve yoğunluklarda faaliyet göstermektedir. Dolayısıyla mezhepçiliği yekpare bir olgu olarak ele almak yanlış çıkarımlara götürecektir. Bu tabakalar arasındaki ilişkinin gösterilmesi, mezhepçilik üzerine çalışmaların temel önceliklerinden biri olmalıdır zira mezhepçiliğin esas dinamiği ilişkiseldir. Ayrıca farklı 
vakalardaki analiz birimleri ortaya çıkarılarak benzerlik ve farklılıkların karşılaştırılmasıyla mezhepçilik konusuna yönelik daha geniş bir çerçeve elde edilebilir.

\section{Kaynakça}

Abbas Aziz ile mülakat, Şubat 2016, Ankara.

Anthony H. Cordesman and Emma R. Davies, Iraq's Insurgency and the Road to Civil Conflict, Westport: Praeger Security International, 2008.

Bilgay Duman, “ABD Güçlerinin 2004-2005 Operasyonları ve Bıraktığ İzler”, Ortadoğu Analiz, 2009, c. 1, sy. 5, s. 39-45.

Bilgay Duman, “Irak’ta Bir Kimlik Arayışı: Bektaşiler”, Ortadoğu Analiz, 2011, c. 3 , sy. 35 , s. $61-68$.

Bilgay Duman, “Türkiye'den Irak'a Uzanan Birlik Köprüsü: Telafer”, $O R$ SAM, 3 Mart 2011.

Bilgay Duman, "Taki el-Mevla ile Türkiye-Irak İlişkileri Sohbetleri”, ORSAM, 18 Haziran 2012.

Bilgay Duman, "Saha Gözlemleri Işığında Necef ve Kerbela'da Yaşayan Telaferli Göçmen Türkmenlerin Durumu”, Ortadoğu Analiz, 2017, c. 9, sy. 79. S. 58-59.

Bilgay Duman ve Feyzullah Tuna Aygün, "Telaferli Türkmen Göçmenlerin Durumu ve Telafer' in Geleceği”, ORSAM Rapor, 2017, sy. 215.

Bill Roggio, "Operation Restoring Rights in Tal Afar", The Long War Journal, 5 Eylül 2005.

Bruce R. Pirnie and Edward O'Connell, Counterinsurgency in Iraq (20032006), CA: RAND Corporation, 2008.

Crispin Smith, "What will a Future Kurdish State Do with its Own Minorities?", Middle East Institute, 6 Eylül 2017.

Cora Govers and Hans Vermeulen, "From Political Mobilization to the Politics of Consciousness", in The Politics of Ethnic Consciousness, ed. Cora Govers and Hans Vermeulen, NY: St. Martin's Press, 1997, 1-30.

David R. McCone, Wilbur J. Scott, and George R. Mastroianni, "The $3^{\text {rd }}$ ACR in Tal'afar: Challenges and Adaptations", Strategic Studies Institute, 2008. 
Edward Schatz, Modern Clan Politics: The Power of "Blood" in Kazakhstan and Beyond, Seattle: University of Washington Press, 2004.

Fanar Haddad, Sectarianism in Iraq: Antagonistic Visions of Unity, London: Hurst \& Company, 2011.

Ferai T1nç, “Türkmen Gözüyle Telafer”, Hürriyet, 20 Nisan 2007.

Ferry Biedermann, "Tel Afer's Ethnic Tug of War Puts Iraq Army to the Test”, Financial Times, 18 Ocak 2006.

Fotini Christia, Elizabeth Dekeyser and Dean Knox, "To Karbala: Survey in Religious Shi'a from Iran and Iraq", Massachusetts Institute of Technology, 2016.

F. Gregory Gause, "Beyond Sectarianism: The New Middle East Cold War", Brookings Doha Center Analysis Paper, 2014, sy. 11.

Gerd Baumann, The Multicultural Riddle: Rethinking Ethnic and Religious Identities, NY: Routledge, 1999.

George Packer, "The Lesson of Tal Afar: Is It Too Late for the Administration to Correct Its Course in Iraq?", The New Yorker, 10 Nisan 2006.

George Scott, "A Resynthesis of Primordial and Circumstantial Approaches to Ethnic Group Solidarity: Towards and Explanatory Model”, Ethnic and Racial Studies, c. 13, sy. 2, s. 147-171.

Harith Hasan al-Qarawee, "Heightened Sectarianism in the Middle East: Causes, Dynamic and Consequences", ISPI Analysis, 2013, sy. 205.

Hassan Hassan, "The Battle for Mosul is a Struggle for Iraq Itself", The National, 16 Ekim 2016.

Helle Malmvig, "Coming in from the Cold: How We May Take Sectarian Identity Politics Seriously in the Middle East without Playing to the Tunes of Regional Power Elites", POMEPS Briefings, 2016, sy. 28, s. 8-12.

"Investing in Iraq's Peace: How Good Governance Can Diminish Support for Violent Extremism”, Mercy Corps, 2015.

"Iraq: Challenges of Forced Displacement within Iraq," Internal Displacement Monitoring Centre, 2008.

"Iraqi Worries and Hopes Regarding Sectarianism", Greenland Quinlan Rosner Research, 2011. 
Jack Eller and Reed Coughlan, "The Poverty of Primordialism", in Ethnicity, ed. John Hutchinson and Anthony D. Smith, Oxford: Oxford University Press, 1996, s. 45-51.

James Cogan, "Iraq: US Occupation Sets off Sectarian Atrocities in Tal Afar”, World Socialist Web Site, 30 Mart 2007.

James McKay, "An Explanatory Synthesis of Primordial and Mobilisationist Approaches to Ethnic Phenomena", Ethnic and Racial Studies, 1982, c. 5 , sy. 4 , s. 395-418.

Jay B. Baker, "Tal Afar 2005: Laying the Counterinsurgency Groundwork", Army, 2009, c. 6, sy. 59, s. 61-68.

Joanne Nagel, "Constructing Ethnicity: Creating and Recreating Ethnic Identity and Culture", in New Tribalisms: The Resurgence of Race and Ethnicity, ed. Michael W. Hueghey, London: MacMillan Press, 1988, s. 237-272.

John R. Ballard, Fighting for Fallujah: A New Dawn for Iraq, London: Praeger Security International, 2006.

Kemal Beyatlı ile mülakat, Mart 2016, İstanbul.

Khalil F. Osman, Sectarianism in Iraq: The Making of State and Nation since 1920, London and NY: Routledge, 2015.

Maja Zehfuss, Constructivism in International Relations: The Politics of Reality, Cambridge: Cambridge University Press, 2004.

Marc Lynch, "Why Saudi Arabia Escalated the Middle East's Sectarian Conflict", The Washington Post, 4 Ocak 2016.

Mansoor Moaddel, Julie de Jong and Munqith Dagher, "Beyond Sectarianism in Iraq", Context, 2011, c. 10, sy. 3, s. 66-67.

Michael Lipka, "The Sunni-Shia Divide: Where They Live, What They Believe and How They View Each Other", Pew Research Center, 18 Haziran 2014.

Mehmet Tütüncü ile mülakat, Mart 2016, İstanbul.

Michael Banton, "The Actor's Model of Ethnic Relations", in Ethnicity, ed. John Hutchinson and Anthony D. Smith, Oxford: Oxford University Press, 1996, s. 98-104. 
Michael Fitzsimmons, Governance, Identity, and Counterinsurgency: Evidence from Ramadi and Tal Afar, PA: US Army War College Press, 2013.

Michael Freeman, "Theories of Ethnicity, Tribalism and Nationalism", in Ethnic Conflict, Tribal Politics: A Global Perspective, ed. Kenneth Christie, Richmond: Curzon Press, 1998, s. 15-33.

Michael Hetcher, "Ethnicity and Rational Choice Theory", in Ethnicity, ed. John Hutchinson and Anthony D. Smith, Oxford: Oxford University Press, 1996, s. 90-98.

Patrick Cockburn, The Occupation: War and Resistance in Iraq, NY: Verso, 2006.

Peter Baker, “An Iraq Success Story's Sad New Chapter”, The Washington Post, 21 Mart 2006.

Sami Ramadani, "The Sectarian Myth of Iraq", The Guardian, 16 Haziran 2014.

Sarah Sewall, John A. Nagl, David H. Petraeus and James F. Amos, The US Army/Marine Corps Counterinsurgency Field Manual, Chicago: University of Chicago Press, 2007.

Serhat Erkmen, "Unutulmuşluğun Karanlığından Umudun Aydınlığına Uzanan Bir Türkmen Kenti: Telafer”, Ortadoğu Analiz, 2009, c. 1, sy. 5, s. 6-22.

Stephan Cornell and Douglas Hartman, Ethnicity and Race: Making Identities in a Changing World, CA: Pine Forge Press, 1998.

Steve Fenton, Ethnicity, Cambridge: Polity Press, 2010.

Suphi Saatçi ile mülakat, Mart 2016, İstanbul.

Thomas Hylland Eriksen, Ethnicity and Nationalism, London \& Virginia: Pluto Press, 2002.

Toby Dodge, "Seeking to Explain the Rise of Sectarianism in the Middle East: The Case Study of Iraq", POMEPS Briefings, 2016, sy. 28, s. 22-28.

Travis Patriquin, "Using Occam's Razor to Connect the Dots: The Baath Party and Insurgency in Tal Afar", Military Review, 2007, c. 1, sy. 2, s. 18-37. 
Ümit Özdağ ve Nevin Yazıc1, “Irak'ta Direnen Bir Türkmen Kenti: Telafer”, 21. Yüzyıl Türkiye Enstitüsü, 16 Haziran 2014.

Vali Nasr, The Shia Revival: How Conflicts within Islam Will Shape the Future, NY: Norton, 2006.

\section{Internet Kaynakları}

“Ankara Türkmenler İçin Devrede”, Deutche Welle, 23 Haziran 2014.

"Another Success? Iraqi Mayor Bush Once Hailed Flees to U.S.", McClatchy Newspapers, 30 Ekim 2008.

"Fear Casts a Shadow on 'Free City' Touted by Bush", Los Angeles Times, 26 Mart 2006.

"Fears of Sectarian Tension as PMUs Close in on Tal Afar", Al Jazeera, 25 Kasim 2016.

“Irak Ordusu Telafer'in Dış Mahallelerine Ulaştı”, NTV, 22 Ağustos 2017.

“Irak’ta Mezhep Kıyımı", Milliyet, 17 Haziran 2014.

"Iraq: Sunnis versus Shia in Tal Afar", Stratfor, 29 Mart 2007.

"Iraq's Turkmen Mobilise for a Post-ISIL future", Al Jazeera, 13 Şubat 2017.

"Iraqi Battle for Mosul Prompts Fears of More Sectarian Violence", CNN, 21 Kasim 2016.

"Iraqi Shi'ite Fighters Mass Near Flashpoint Town West of Mosul", Reuters, 21 Kasim 2016.

"ISIS Attempting to Stir Sectarian Hatred with Murals in Tal Afar, Iraq", Al Masdar, 21 Ocak 2017.

"Isis is Full of Killers, the Worst Come from Tal Afar: Bitter Fight for City Ahead and the Violence May not End There", The Independent, 15 Kasim 2016.

"Many Sunnis and Shias Worry About Religious Conflict", Pew Research Center, 7 Kasim 2013.

"Sheiks' Deaths Lead to Questions on Progress", Stars and Stripes, 12 Haziran 2008. 
“Şii Milis Haşdi Şabi Telafer’e İlerliyor”, NTV, 3 Kasım 2016.

"Tal Afar Sunnis Oppose Shiite Hashd Forces Entering Their Town", $R u$ daw, 19 Kasım 2016.

"Tal Afar,Wwest of Mosul, Becomes Center of Battle for Influence in Iraq", The New York Times, 29 Ekim 2016.

“Telafer’de Operasyon Başladı”, Milliyet, 21 Ağustos 2017.

“Telafer'den Göç Eden Türkmenler Türkiye Sınırına Ulaştı", Anadolu Ajansı, 5 Aralık 2016.

“Telafer’e Dokunan Türkiye’ye Dokunur”, Hürriyet, 26 Şubat 2011.

“Telafer'i DEAŞ’tan Kurtarma Operasyonu Başladı”, CNN Türk, 20 Ağustos 2017.

“Türkmenlerin Telafer Endişesi”, Türkiye Gazetesi, 9 Ağustos 2017.

"UNAMI Submits its Reports on the Disputed Internal Boundaries", United Nations Iraq, 22 Nisan 2009.

"Under Pressure, Rebels Abandon an Iraqi Stronghold", The New York Times, 12 Eylül 2005.

"US Drawdown Raises Security Fears in Iraqi City", USA Today, 17 Ağustos 2008 . 